\title{
Peripheral regulatory cells immunophenotyping in Primary Sjögren's Syndrome: a cross-sectional study
}

Janette Furuzawa-Carballeda ${ }^{\dagger}$, Gabriela Hernández-Molina ${ }^{\dagger}$, Guadalupe Lima, Yahaira Rivera-Vicencio, Karen Férez-Blando and Luis Llorente*

\begin{abstract}
Introduction: IL-10-producing B cells, Foxp3-expressing T cells (Tregs) and the IDO-expressing dendritic cells (pDC) are able to modulate inflammatory processes, to induce immunological tolerance and, in turn, to inhibit the pathogenesis of autoimmune disease.

The aim of the study was to characterize and to enumerate peripheral IL-10-producing B cells, Tregs and pDCregs in primary Sjögren's Syndrome (pSS) patients in regard of their clinical and serologic activity.
\end{abstract}

Methods: Fifty pSS patients and 25 healthy individuals were included in the study. CD19+expressing peripheral B

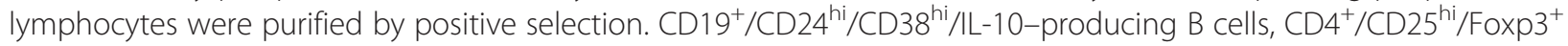
and $\mathrm{CD}^{+} / \mathrm{CD}_{28} / \mathrm{Foxp}^{+}$Tregs, as well as $\mathrm{CCR}^{+} / \mathrm{CD} 123^{+} / \mathrm{IDO}^{+} \mathrm{DCs}$, were quantitated by flow cytometry.

Results: Immature/transitional circulating IgA $\mathrm{A}^{+} \mathrm{L}-10$-producing B cells had higher levels in pSS patients versus control group, whereas $\mathrm{CD} 19^{+} / \mathrm{CD} 38^{\text {hi }} / \mathrm{IgG}^{+} / \mathrm{IL}-10^{+}$cells had lower percentage versus control. Indeed $\mathrm{CD} 19^{+} / \mathrm{CD} 24^{\text {hi }} / \mathrm{CD} 38^{\text {hi }} /$ $\mathrm{CD}^{+} / \mathrm{IL}-10^{+}, \mathrm{CD} 19^{+} / \mathrm{CD} 24^{\mathrm{hi}} / \mathrm{CD} 38^{\mathrm{hi}} / \mathrm{CD} 10^{+} / \mathrm{LL}-10^{+}, \mathrm{CD} 19^{+} / \mathrm{CD} 24^{\mathrm{hi}} / \mathrm{CD} 38^{\mathrm{hi}} / \mathrm{CD} 20^{+} / \mathrm{LL}-10^{+}, \mathrm{CD} 19^{+} / \mathrm{CD} 24^{\mathrm{hi}} / \mathrm{CD} 38^{\mathrm{hi}} / \mathrm{CD} 27^{-} / \mathrm{LL}-$ $10^{+}$, and $\mathrm{CD} 19^{+} / \mathrm{CD} 24^{\mathrm{hi}} / \mathrm{CD} 38^{\mathrm{hi}} / \mathrm{CXCR} 7^{+} / \mathrm{LL}-10^{+}$cells had higher frequency in clinical inactive pSS patients when compared with control group. Remarkably, only percentages of CD $19^{+} / \mathrm{CD} 24^{\mathrm{hi}} / \mathrm{CD} 38^{\mathrm{hi}} / \mathrm{CD} 10^{+} / \mathrm{LL}-10^{+}$and $\mathrm{CD} 19^{+} /$ $\mathrm{CD} 24^{\text {hi }} / \mathrm{CD} 38^{\text {hi }} / \mathrm{CD} 27^{-} / \mathrm{LL}-10^{+}$subsets were increased in $\mathrm{pSS}$ serologic inactive versus control group $(P<0.05)$. The percentage of IDO-expressing PDC cells was higher in pSS patients regardless of their clinical or serologic activity. There were no statistically significant differences in the percentage of $\mathrm{CD}^{+} / \mathrm{CD} 25^{\mathrm{hi}} / \mathrm{Foxp}^{+}$Tregs between patient groups versus controls. Nonetheless, a decrease in the frequency of $\mathrm{CD}^{+} / \mathrm{CD}^{2} 8^{-} / \mathrm{Foxp}^{+}$Tregs was found in inactive pSS patients versus controls $(P<0.05)$.

Conclusions: The findings of this exploratory study show that clinical inactive pSS patients have an increased frequency of IL-10-producing B cells and IDO-expressing pDC cells.

\section{Introduction}

Progress in clarifying cellular, molecular and biochemical processes that regulate immune response provides increasingly acceptable enlightenment for the normal status of tolerance to self-antigens that guards most humans from Ehrlich's imagined horror, autotoxicus [1]. Emerging data on the IL-10-producing B-cell subset provide fertile ground for resolving some perplexing immunological

\footnotetext{
*Correspondence: luisllorentepeters57@gmail.com

† Contributed equally

Department of Immunology and Rheumatology, Instituto Nacional de Ciencias Médicas y Nutrición Salvador Zubirán, Vasco de Quiroga No. 15, Col. Sección XVI, CP 14000, Mexico City, Mexico
}

paradoxes. The immunoregulatory role of $\mathrm{B}$ cells in autoimmune disease was initially characterized in B celldeficient mice immunized with a myelin basic protein peptide in complete Freund's adjuvant, where mice develop exacerbated encephalomyelitis compared to controls [2]. This Breg subset differentiates in a chronic inflammatory environment, expresses high levels of CD1d, produces IL-10, and suppresses the progression of intestinal inflammation by directly downregulating inflammatory cascades associated with IL- $1 \beta$ and signal transducer and activator of transcription 3 (STAT3) activation [3,4]. Lately, it has been described as a $\mathrm{CD} 19^{+} \mathrm{CD} 24^{\mathrm{hi}} \mathrm{CD} 38^{\mathrm{hi}}$

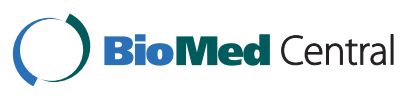

(c) 2013 Furuzawa-Carballeda et al.; licensee BioMed Central Ltd. This is an open access article distributed under the terms of the Creative Commons Attribution License (http://creativecommons.org/licenses/by/2.0), which permits unrestricted use, distribution, and reproduction in any medium, provided the original work is properly cited. 
immature/transitional B-cell subset that suppresses the differentiation of T helper (Th) 1 cells in an IL-10dependent, but TGF- $\beta$-independent manner, which requires $\mathrm{CD} 80 / \mathrm{CD} 86$ interactions with target $\mathrm{CD} 4^{+}$ $\mathrm{T}$ cells. Remarkably, it has been shown that in patients with systemic lupus erythematosus (SLE), the CD19 ${ }^{+}$ CD $24{ }^{\text {hi }}$ CD $38^{\text {hi }}$ B subset produces less IL-10 in response to $\mathrm{CD} 40$ stimulation and is unable to inhibit Th responses, suggesting that altered cellular function of the subpopulation in SLE may impact the immune effector responses in this autoimmune disease [4]. Furthermore, in renal transplant patients, increased frequency of $\mathrm{CD} 19^{+} \mathrm{CD} 24^{\mathrm{hi}} \mathrm{CD} 38^{\mathrm{hi}}$ has been associated with operational tolerance [5-8]. In addition, these IL10-producing $\mathrm{B}$ cells favor the differentiation and maintenance of regulatory Foxp3-expressing $\mathrm{T}$ cells (Tregs) and may control organ-specific inflammation $[3,4,9]$.

On the other hand, the catabolism of tryptophan, by the enzyme indoleamine 2,3-dioxygenase (IDO) expressed in plasmacytoid dendritic cells (pDCs), generates kynurenines, 3-hydroxyanthranilic, and quinolic acids, molecules with the ability to induce Th1 over Th2-cell apoptosis and to exert cytotoxic action on T, B and natural killer (NK) cells, but not on dendritic cells (DCs) themselves [10,11]. IDO has a selective sensitivity for Th1 over Th2 cells to tryptophan metabolites, suggesting a potential role for Th2 differentiation [12]. Furthermore, deprivation of tryptophan by IDO halts the proliferation of T cells at mid- $\mathrm{G}_{1}$ phase, which in concert with the pro-apoptotic activity of kynurenine, leads to diminishing $\mathrm{T}$ cell-mediated immune responses and the subsequent development of immune tolerance [13-17]. As IL-10-producing B cells, IDO-competent DCs have been shown to induce IL-10-producing Treg cells (Tr1) and CD $4^{+} / \mathrm{CD} 25^{\mathrm{hi}} / \mathrm{Foxp} 3^{+}$Tregs in vivo, and Treg-expressed glucocorticoid-induced TNF receptor (GITR), which in turn, can use IDO ${ }^{+}$DCs to expand their own population in a positive feedback loop [18-20].

Thus, quantitative and functional modifications of IL-10producing B cells, Tregs and IDO-producing cells, might play a role in the pathogenesis and disease activity of autoimmune systemic disorders, including primary Sjögren's syndrome (pSS) [21], an autoimmune exocrinopathy characterized by chronic lymphocytic inflammation of the lacrimal and salivary glands resulting in keratoconjunctivitis sicca and xerostomia. Indeed, there are several features of systemic disease that may also involve additional organ systems. Although the glandular destruction has been shown to be mainly mediated by $\mathrm{CD} 45 \mathrm{RO}^{+} / \mathrm{CD}^{+} \mathrm{T}$ lymphocytes, chronic $\mathrm{B}$ cell activation and proliferation seem to play an intimate role [22]. In this vein, evidence of B cell hyperactivity, including circulating immune complexes, hypergammaglobulinemia, and/or autoantibodies, are frequently found in patients with pSS [22-25]. Moreover, it has been demonstrated that patients with pSS exhibit disturbed Bcell subset distribution in their blood [2].

In order to delineate the peripheral cell types with regulatory properties in patients with pSS, the aim of this study was to characterize and to enumerate IL-10producing B cell subpopulations according to previous immunophenotyping studies [4,26,27], Foxp3-expressing $\mathrm{CD} 4^{+} / \mathrm{CD} 25^{\mathrm{hi}}$ and $\mathrm{CD} 8^{+} / \mathrm{CD} 28^{-} \mathrm{T}$ cells, and IDO-producing $\mathrm{CCR}^{+} / \mathrm{CD} 123^{+}$DCs by flow cytometry.

\section{Material and methods \\ Patients}

For this exploratory, observational, cross-sectional study, we included 50 consecutive pSS patients regularly attending the Department of Immunology and Rheumatology at the Instituto Nacional de Ciencias Médicas y Nutrición Salvador Zubirán, a tertiary care center. Eligible patients had to fulfill the American-European Consensus Group criteria for pSS [28], not meet classification criteria for any other autoimmune disease and not have concomitant lymphoma. All patients had a face-to-face interview with one rheumatologist (GH) using a standardized form, which included questions about demographic data, use of medications and symptoms. Patients may or not have been receiving prednisone or immunosuppressors at the time of the assessment; however they were not included if concomitant infection was present. Furthermore, disease activity status was assessed using the European League Against Rheumatism (EULAR) Sjögren's syndrome disease activity index (ESSDAI) [29] and Sjögren's syndrome disease activity index (SSDAI) validated scales [30]. Both indexes evaluate glandular (enlarged parotid glands) and extraglandular features such as fatigue, non-erosive arthritis, skin vasculitis, interstitial lung disease, renal involvement, neurological involvement, myositis, lymphadenopathy/splenomegaly, hematological involvement and fever. In addition the ESSDAI has a biological domain that evaluates hypocomplementemia, cryoglobulinemia, hypergammaglobulinemia or high immunoglobulin G (IgG) levels. For the present study, the patients were allocated to two groups, those with clinically active disease $(n=17)$ and those with clinically inactive disease $(n=33)$. We defined clinically active disease as the presence of one or more glandular and extraglandular features recognized by the ESSDAI and SSDAI with the exception of fatigue. If any manifestation could be secondary to other concomitant condition besides SS, the feature was not considered as part of the activity assessment. Finally patients' clinical records were carefully reviewed to collect information about the disease onset and follow-up. In addition 25 age-matched healthy donors (HD) were included as controls. HD were also interviewed to discard any known autoimmune disease, use of immunosuppressors and prednisone and concurrent infections. 
The protocol was approved by the Committee of Medical Ethics (Reference number 348) and performed in accordance with the revised Declaration of Helsinki. All patients gave written informed consent to participate.

\section{Serologic markers}

Levels of serum IgG, IgM, IgA, C3 and C4 complement proteins were determined by immunoturbidimetry, serum hyperviscosity was assessed with an Ostwald viscometer, and erythrocyte sedimentation rate (ESR) was determined by the Westergren method at the assessment. Serologic activity was defined as the presence of one or more of the following features: serum viscosity $>2$ AU, elevated IgG $(>1,741 \mathrm{mg} / \mathrm{dL}), \operatorname{IgM}(>281 \mathrm{mg} / \mathrm{dL})$, IgA ( $>433 \mathrm{mg} / \mathrm{dL})$ or decreased levels of complement C3 (<90 mg/dL) and C4 (<10 mg/dL).

\section{Isolation of peripheral blood mononuclear cells (PBMC)}

A sample of venous blood $(120 \mathrm{~mL})$ was obtained from each subject. PBMC were isolated by gradient centrifugation on the Lymphoprep (Axis-Shield PoC AS, Oslo, Norway).

\section{B-cell purification and cytometric analysis}

CD19-mAb-coated microbeads (Miltenyi Biotec, Bergisch Gladbach; Germany) were used to purify blood B cells by positive selection following the manufacturer's instructions. Purity was assessed by fluorescence-activated cell sorting (FACS) staining for the B- and T-cell markers. Thus, anti-human CD19-PE and anti-human CD3-FITC monoclonal antibodies were used. This procedure normally yielded B-cell preparations which were $>95 \%$ CD19+.

\section{Flow cytometry}

CD $19^{+}$cells were surface stained with several combinations of anti-human fluorochrome-conjugated antibodies for four-color analysis. CD $19^{+}$cells were stained with $5 \mu \mathrm{L}$ of anti-CD38-PECy5-labeled (clone: HIT2), antiCD38-PE-conjugated (clone: HIT2), anti-CD24-FITClabeled (clone: ML5), anti-IgG-PECy5-conjugated (clone: G18-145), anti-IgM-APC-labeled (clone: G20-127), antiCD5-APC-conjugated (clone: L17F12), anti-CD10-APClabeled (clone: HI10a), anti-CD20-APC-conjugated (clone: 2H7), anti-CD27-APC-labeled (clone: M-T271), anti-CXRC4-APC-conjugated (clone: 12G5) (BD Biosciences, San Jose, CA, USA), anti-CXCR7 (polyclonal, Abcam Inc, Cambridge, MA, USA), anti-rabbit IgG-Cy5labeled polyclonal antibody (Abcam Inc,) and anti-IgAPE-conjugated (clone: 11-44-2, eBioscience, San Diego, CA, USA). CD19 ${ }^{+}$cells were permeabilized with $200 \mu \mathrm{L}$ of cytofix/cytoperm solution (BD Biosciences) at $4^{\circ} \mathrm{C}$ for 20 minutes, then they were stained for intracellular IL-
10 with PE-conjugated-anti-IL-10 (clone: JES3-19F1, BD Biosciences) or fluorescein isothiocyanate (FITC)labeled-anti-IL-10 (clone: BT10, eBioscience). Finally, $\mathrm{CD}_{19^{+}}$subsets were analyzed by flow cytometry with a FACScalibur (BD Biosciences). An electronic gate was made for $\mathrm{CD} 38^{\mathrm{hi}}$, $\mathrm{IgA}^{+}, \mathrm{IgG}^{+}$, or $\mathrm{IgM}^{+}$and $\mathrm{IL}-10^{+}$or for $\mathrm{CD} 19^{+} / \mathrm{CD} 38^{\mathrm{hi}} / \mathrm{CD} 24^{\mathrm{hi}}, \mathrm{CD} 5^{+}, \mathrm{CD} 10^{+}, \mathrm{CD} 20^{+}, \mathrm{CD} 27^{+}$, $\mathrm{CXCR}_{4}{ }^{+}$or $\mathrm{CXCR}^{+}$and $\mathrm{IL}-10^{+}$cells and a total of 50,000 to 100,000 events were recorded for each sample and analyzed with the CellQuestPro software (BD Biosciences). Results are expressed as the relative percentage of IL-10-expressing B cells in each gate. As isotype controls, IgG 1 -FITC/IgG 1 -PE/CD45-PeCy5 mouse IgG $_{1}$, k (BD Tritest ${ }^{\mathrm{TM}}, \mathrm{BD}$ Biosciences) and PE-conjugated-anti rat-IL-10 IgG (clone: R35-95, BD Biosciences) were used to set the threshold and gates in the cytometer. We ran an unstained (autofluorescence control) and permeabilized PBMC sample. Autofluorescence control was compared to single-stained cell-positive controls to confirm that the stained cells were on scale for each parameter.

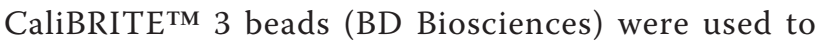
adjust instrument settings, set fluorescence compensation, and check instrument sensitivity.

To determine IDO cell expression, non-B cells (unlabeled cells obtained from the column while the magnetically labeled $\mathrm{CD} 19^{+} \mathrm{B}$ cells were retained on the column) were conjugated with an anti-human CCR6-PE (clone: 11A9) and CD123-PECy5 (clone: 9F5) monoclonal antibodies (BD Biosciences). Cells were permeabilized and stained with a polyclonal sheep anti-human-IDO (Pierce Biotechnology, Rockford, IL, USA) and then with FITCconjugated-rabbit polyclonal anti-sheep antibody (Chemicon, Temecula, CA, USA). The cell subset was analyzed by flow cytometry. As the control for FITC-labeled rabbit anti-sheep specificity staining, cells were incubated with surface antibodies and FITC-conjugated rabbit anti-sheep in the absence of sheep anti-human IDO antibody. An electronic gate was made for each of the surface markers employed. Results are expressed as the relative percentage of IDO-expressing cells in each gate.

For Tregs, non-CD $19^{+} \mathrm{B}$ cells were labeled with an antihuman CD4-FITC (clone: RPA-T4) and CD25-PECy5 (clone: M-A251) or CD8 $\alpha$-FITC (clone: HIT-8a) and CD28-PECy5 (clone: CD28.2) (BD Biosciences). Intracellular staining was performed with an anti-human Foxp3-PEconjugated monoclonal antibody (clone: 259D/C7) (BD Biosciences). An electronic gate was made for CD4 ${ }^{+} / \mathrm{CD} 25^{\mathrm{hi}}$ cells or $\mathrm{CD}^{+} / \mathrm{CD} 28^{-}$. Results are expressed as the relative percentage of Foxp3-expressing cells in each gate. The relative percentage of IL-10-producing B cells, pDC $\mathrm{IDO}^{+}$and Foxp $3^{+}$Treg circulating cells was obtained from the percentage of $\mathrm{CD} 19^{+} / \mathrm{CD} 38^{\mathrm{hi}} / \mathrm{CD} 24^{\mathrm{hi}} / \mathrm{IL}-10^{+}, \mathrm{CCR}^{+} /$ $\mathrm{CD} 123^{\text {hi }}, \mathrm{CD}^{+} / \mathrm{CD} 25^{\text {hi }}$ or $\mathrm{CD}^{+} / \mathrm{CD} 28^{-}$cells, respectively. 


\section{Statistics}

Descriptive statistics were performed and categorical variables were compared using the $X^{2}$ test or Fisher's exact test; for analysis of continuous variables the Student $t$-test was employed. One-way analysis of variance on ranks using the Dunn method was performed for all pairwise multiple comparison procedures. Statistical analysis was done using the SigmaStat11.2 program (Aspire Software International, Leesburg, VA, USA). Data were expressed as the median and range, or mean \pm $\mathrm{SD} /$ standard error of the mean (SEM). P-values smaller than or equal to 0.05 were considered significant.

\section{Results}

\section{Demographic, clinical and laboratory data}

Clinical, demographic and serological variables of patients are summarized in Table 1 and Figure 1. Of 50 patients with pSS $96 \%$ percent were female with a mean age of $53 \pm 12$ years, median disease duration of 9.7 years ( 0.97 to 42.0 years), and median disease activity score of $0(0-6)$ assessed by the SSDAI and 1 (0 to 5 ) assessed by the ESSDAI. For therapy, 22\% were receiving prednisone and 38\% were receiving at least one immunosuppressor as follows: antimalarial drugs, 11 patients (22\%); azathioprine, 6 patients (12\%); methotrexate, 5 patients (10\%); and cyclophosphamide, 2 patients $(4 \%)$. Seventeen patients (34\%) had clinical activity manifested as parotid enlargement, vasculitis, arthritis, leukopenia, lymphopenia, pneumonitis and optic neuritis.

Forty-four percent (27/50) of patients had serological activity (with or without concomitant clinically active disease). There was no difference in the use of steroids or immunosuppressors in patients with and without serologic activity, no difference in the age of patients with active or inactive disease ( 49 versus 55 years, $P=0.07$ ) and no difference in disease duration (10.9 versus 7.7 years, $P=0.24)$. However, as expected, patients with clinically active disease had higher SSDAI and ESSDAI scores (Table 1) and more frequently received prednisone $(53 \%$ versus $6 \%, P=0.001)$. On the other hand, patients with clinically active disease more frequently received immunosuppressors (58\% versus $30 \%$ ), but this difference was not statistically significant $(P=0.06)$. The frequency of medication use was as follows: azathioprine, $29 \%$ versus $3 \%(P=0.01)$; methotrexate, $17 \%$ versus $6 \%$; cyclophosphamide, $5 \%$ versus $3 \%,(P=0.54)$; and antimalarial drugs, $35 \%$ versus $21 \%(P=0.78)$, among patients with clinically active and inactive disease, respectively.

Peripheral IL-10-producing B cells in patients with pSS To determine the different subtypes of IL-10-producing B cells, first CD $19^{+} / \mathrm{CD} 38^{\mathrm{hi}} / \mathrm{CD} 24^{\mathrm{hi}} / \mathrm{IL}-10^{+}$immature/ transitional circulating cells were identified and subsequently they were subphenotyped by determining the Ig expression on their surface (Table 2). Compared with healthy subjects, the $\mathrm{CD} 19^{+} / \mathrm{CD} 38^{\text {hi }} / \mathrm{CD} 24^{\text {hi }} / \mathrm{IL}-10$ producing B-cell subpopulation $(0.20 \pm 0.02 \%$ in healthy subjects) was greater in pSS patients with clinically inactive disease $(0.63 \pm 0.06 \%)$, with clinically active disease $(0.55 \pm 0.05 \%)$, with positive serology $(0.57 \pm 0.07 \%)$ and without serologic activity $(0.53 \pm 0.07 \%)(P<0.05)$ (Table 2; Figure 2A). However, no differences were found in the frequency of circulating $\mathrm{CD} 19^{+} / \mathrm{CD} 38^{\mathrm{hi}} / \mathrm{IL}-$ $10^{+} \mathrm{B}$ cells among groups of patients (Table 2 ).

For Ig surface expression, no changes were found in the $\mathrm{CD} 19^{+} / \mathrm{CD} 8^{\mathrm{hi}} / \mathrm{IgM}^{+} / \mathrm{IL}-10^{+}$B-cell subpopulation between patient subgroups (Table 2; Figure 3I). However, the relative frequency of $\mathrm{CD} 19^{+} / \mathrm{CD} 38^{\mathrm{hi}} / \mathrm{IgG}^{+} / \mathrm{IL}-$ $10^{+}$was lower in all pSS subgroups when compared with the healthy control group (Table 2; Figure 3J). pSS patients with clinical activity had significantly lower levels of $\mathrm{CD} 19^{+} / \mathrm{CD} 38^{\mathrm{hi}} / \mathrm{IgG}^{+} / \mathrm{IL}-10^{+}$compared to those with clinically inactive disease $(38.6 \pm 3.7$ versus $48.1 \pm$ 2.0\%; $P<0.05$ ) (Table 2; Figure 3J). With the exception of pSS patients with clinically active disease, all pSS subgroups had higher frequency of $\mathrm{CD} 19^{+} / \mathrm{CD} 38^{\mathrm{hi}} / \mathrm{IgA}^{+} / \mathrm{IL}-$ $10^{+} \mathrm{B}$ cells compared with the healthy control group $(P<0.05)$ (Table 2; Figure $3 \mathrm{~L})$. It is important to recall that the results are expressed as the relative percentage obtained from CD $19^{+} / \mathrm{CD} 38^{\mathrm{hi}} / \mathrm{IL}-10^{+}$B cells (Table 2 ).

The frequency of immature/transitional CD $19^{+} / \mathrm{CD} 38^{\text {hi }}$ / $\mathrm{CD} 24^{\mathrm{hi}} / \mathrm{CD}^{+} / \mathrm{IL}-10^{+} \mathrm{B}$ cells was higher in patients without clinical activity and lower in patients with clinical activity when compared with the control group $(P<0.05)$ (Table 2; Figure 4E). The percentage of CD19 ${ }^{+} / \mathrm{CD} 38^{\mathrm{hi}} /$ $\mathrm{CD} 24^{\mathrm{hi}} / \mathrm{CD} 10^{+} / \mathrm{IL}-10^{+}$was higher in $\mathrm{pSS}$ patients who had both clinical and serologic inactivity when compared to healthy subjects $(P<0.05)$ (Table 2 ; Figure $4 \mathrm{~F})$. Moreover, CD $19^{+} / \mathrm{CD} 38^{\mathrm{hi}} / \mathrm{CD} 24^{\mathrm{hi}} / \mathrm{CD} 10^{+} / \mathrm{IL}-10^{+}$circulating B cells were higher in pSS patients with clinically inactive versus clinically active disease, and in pSS patients without serologic activity versus pSS patients with serologic activity $(P<0.05)$ (Table 2; Figure 4F). The percentage of $\mathrm{CD} 19^{+} /$ CD $38^{\text {hi }} / \mathrm{CD} 24^{\mathrm{hi}} / \mathrm{CD} 20^{+} / \mathrm{IL}-10^{+}$was higher in pSS patients with clinically inactive disease when compared to healthy subjects, and to pSS patients with clinically active disease $(P<0.05)$ (Table 2; Figure 4G).

In addition, a different IL-10 B subset, a non-memory $B$ cell that could be the human counterpart of mouse marginal-zone B cells, a CD $19^{+} / \mathrm{CD} 38^{\text {hi }} / \mathrm{CD} 24^{\text {hi }} / \mathrm{CD} 27^{+}$ B10 subset was also immunophenotyped. No statistically significant differences were found in the B10 subset between pSS patients and the control group (Table 2). Nonetheless, the percentage of CD $19^{+} / \mathrm{CD} 38^{\text {hi }} / \mathrm{CD} 24^{\text {hi }}$ / $\mathrm{CD} 27^{-} / \mathrm{IL}-10^{+}$cells was increased in pSS patients independently of clinical or serologic activity $(P<0.050$ 
Table 1 Demographic and clinical characteristics of patients with primary Sjögren's syndrome

\begin{tabular}{|c|c|c|c|c|c|c|c|c|c|c|}
\hline Variable & $\begin{array}{l}\text { Control } \\
(n=25)\end{array}$ & $\begin{array}{c}\text { All } \\
\text { pSS } \\
\text { patients } \\
(n=50)\end{array}$ & $\begin{array}{c}\text { Clinically } \\
\text { active } \\
\text { pSS patients } \\
(n=17)\end{array}$ & $\begin{array}{c}\text { Clinically } \\
\text { inactive } \\
\text { pSS patients } \\
(n=33)\end{array}$ & $\begin{array}{l}\text { Serologically } \\
\text { active } \\
\text { pSS patients } \\
(n=29)\end{array}$ & $\begin{array}{l}\text { Serologically } \\
\text { inactive } \\
\text { pSS patients } \\
(n=18)\end{array}$ & $\begin{array}{l}\text { Clinically and } \\
\text { serologically } \\
\text { active pSS } \\
\text { patients } \\
(n=12)\end{array}$ & $\begin{array}{l}\text { Clinically } \\
\text { active and } \\
\text { serologically } \\
\text { inactive } \\
\text { pSS patients } \\
(n=4)\end{array}$ & $\begin{array}{l}\text { Clinically inactive } \\
\text { and serologically } \\
\text { active pSS patients } \\
\qquad(n=17)\end{array}$ & $\begin{array}{c}\text { Clinically and } \\
\text { serologically } \\
\text { inactive pSS } \\
\text { patients } \\
(n=14)\end{array}$ \\
\hline \multicolumn{11}{|l|}{ Demographic } \\
\hline $\begin{array}{l}\text { Age (years) } \\
\text { Mean } \pm \text { SD } \\
\text { Median } \\
\text { Range }\end{array}$ & $\begin{array}{c}49.1 \pm 11.0 \\
48.5 \\
23 \text { to } 75\end{array}$ & $\begin{array}{c}53.1 \pm 12.2 \\
53.0 \\
30 \text { to } 77\end{array}$ & $\begin{array}{c}50.4 \pm 11.8 \\
48.5 \\
30 \text { to } 73\end{array}$ & $\begin{array}{c}54.4 \pm 12.4 \\
53.0 \\
33 \text { to } 77\end{array}$ & $\begin{array}{c}51.1 \pm 10.0 \\
50.0 \\
33 \text { to } 73\end{array}$ & $\begin{array}{c}55.1 \pm 14.6 \\
56.0 \\
30 \text { to } 77\end{array}$ & $\begin{array}{c}50.6 \pm 10.7 \\
48.0 \\
33 \text { to } 73\end{array}$ & $\begin{array}{c}51.5 \pm 17.3 \\
52.0 \\
30 \text { to } 72\end{array}$ & $\begin{array}{c}51.8 \pm 10.3 \\
51.5 \\
33 \text { to } 72\end{array}$ & $\begin{array}{c}56.2 \pm 14.3 \\
58.0 \\
34 \text { to } 77\end{array}$ \\
\hline Sex (female/male) & $20 / 5$ & $48 / 2$ & $16 / 1$ & $32 / 1$ & $28 / 1$ & $17 / 1$ & $12 / 0$ & $3 / 1$ & $16 / 1$ & $14 / 0$ \\
\hline \multicolumn{11}{|l|}{ Clinical } \\
\hline $\begin{array}{l}\text { SSDAl } \\
\text { Mean } \pm \text { SD } \\
\text { Median } \\
\text { Range }\end{array}$ & & $\begin{array}{l}0.9 \pm 1.5 \\
0.0 \\
0 \text { to } 6\end{array}$ & $\begin{array}{c}2.5 \pm 1.6 \\
3.0 \\
0 \text { to } 6\end{array}$ & $\begin{array}{c}0.1 \pm 0.3 \\
0.0^{\mathrm{a}} \\
0 \text { to } 1\end{array}$ & $\begin{array}{c}1.3 \pm 1.7 \\
1.0 \\
0 \text { to } 6\end{array}$ & $\begin{array}{c}0.4 \pm 0.85 \\
0.0 \\
0 \text { to } 3\end{array}$ & $\begin{array}{c}2.8 \pm 1.6 \\
3.0 \\
1 \text { to } 6\end{array}$ & $\begin{array}{c}1.5 \pm 1.3 \\
1.5 \\
0 \text { to } 3\end{array}$ & $\begin{array}{c}0.2 \pm 0.4 \\
0.0 \\
0 \text { to } 1\end{array}$ & $\begin{array}{c}0.1 \pm 0.3 \\
0.0 \\
0 \text { to } 1\end{array}$ \\
\hline $\begin{array}{l}\text { ESSSDAI } \\
\text { Mean } \pm \text { SD } \\
\text { Median } \\
\text { Range }\end{array}$ & & $\begin{array}{c}1.5 \pm 1.3 \\
1.0 \\
0 \text { to } 5\end{array}$ & $\begin{array}{c}2.6 \pm 1.2 \\
2.0 \\
1 \text { to } 5\end{array}$ & $\begin{array}{l}0.9 \pm 0.9 \\
1.0^{a} \\
0 \text { to } 3\end{array}$ & $\begin{array}{c}2.0 \pm 1.1 \\
2.0 \\
1 \text { to } 5\end{array}$ & $\begin{array}{c}0.4 \pm 0.9 \\
0.0 \\
0 \text { to } 3\end{array}$ & $\begin{array}{c}2.8 \pm 1.2 \\
2.5 \\
1 \text { to } 5\end{array}$ & $\begin{array}{c}1.8 \pm 1.0 \\
1.5 \\
1 \text { to } 3\end{array}$ & $\begin{array}{c}1.5 \pm 0.6 \\
1.0 \\
1 \text { to } 3\end{array}$ & $\begin{array}{c}0.0 \pm 0.0 \\
0.0^{\mathrm{d}} \\
0 \text { to } 0\end{array}$ \\
\hline \multicolumn{11}{|l|}{ Laboratory } \\
\hline $\begin{array}{l}\text { ESR }(\mathrm{mm} \mathrm{Hg}) \\
\text { Mean } \pm \mathrm{SD} \\
\text { Median } \\
\text { Range }\end{array}$ & & $\begin{array}{c}21.3 \pm 16.3 \\
15.0 \\
2 \text { to } 73\end{array}$ & $\begin{array}{c}23.9 \pm 15.7 \\
22.0 \\
2 \text { to } 59\end{array}$ & $\begin{array}{c}19.5 \pm 16.9 \\
14.0 \\
4 \text { to } 73\end{array}$ & $\begin{array}{c}28.6 \pm 18.0 \\
26.0 \\
6 \text { to } 73\end{array}$ & $\begin{array}{c}12.1 \pm 8.4 \\
9.5^{b} \\
2 \text { to } 29\end{array}$ & $\begin{array}{c}29.8 \pm 14.6 \\
27.0 \\
8 \text { to } 59\end{array}$ & $\begin{array}{c}7.0 \pm 3.4 \\
8.5^{c} \\
2 \text { to } 9\end{array}$ & $\begin{array}{c}27.3 \pm 21.8 \\
16.0 \\
6 \text { to } 73\end{array}$ & $\begin{array}{c}13.8 \pm 8.9 \\
12.5 \\
4 \text { to } 29\end{array}$ \\
\hline $\begin{array}{l}\text { Serum IgM }(\mathrm{mg} / \mathrm{dL}) \\
\text { Mean } \pm \mathrm{SD} \\
\text { Median } \\
\text { Range }\end{array}$ & & $\begin{array}{c}208.1 \pm \\
169.8 \\
178.5 \\
28 \text { to } 1170\end{array}$ & $\begin{array}{c}186.1 \pm 70.2 \\
179.5 \\
52 \text { to } 303\end{array}$ & $\begin{array}{c}219.8 \pm 204.3 \\
178.5 \\
28 \text { to } 1170\end{array}$ & $\begin{array}{c}204.3 \pm 90.1 \\
186.0 \\
70 \text { to } 553\end{array}$ & $\begin{array}{c}214.6 \pm 258.4 \\
146.0 \\
28 \text { to } 1170\end{array}$ & $\begin{array}{c}198.3 \pm 65.5 \\
201.0 \\
96 \text { to } 303\end{array}$ & $\begin{array}{c}149.5 \pm 80.9 \\
148.0 \\
52 \text { to } 250\end{array}$ & $\begin{array}{c}208.5 \pm 105.9 \\
182.0 \\
70 \text { to } 553\end{array}$ & $\begin{array}{c}234.6 \pm 292.5 \\
137.0 \\
28 \text { to } 1,170\end{array}$ \\
\hline $\begin{array}{l}\text { Serum lgG }(\mathrm{mg} / \mathrm{dL}) \\
\text { Mean } \pm \text { SD } \\
\text { Median } \\
\text { Range }\end{array}$ & & $\begin{array}{c}1779.8 \pm \\
703.9 \\
1,554.0 \\
639 \text { to } 3,224\end{array}$ & $\begin{array}{c}1973.4 \pm \\
782.2 \\
1,948.0 \\
825 \text { to } 3,029\end{array}$ & $\begin{array}{c}1676.6 \pm \\
648.6 \\
1,531.0 \\
639 \text { to } 3,324\end{array}$ & $\begin{array}{c}2092.1 \pm 690.9 \\
2,087.0 \\
674 \text { to } 3,224\end{array}$ & $\begin{array}{c}1247.1 \pm \\
282.6 \\
1,310.0^{\mathrm{b}} \\
639 \text { to } 1,738\end{array}$ & $\begin{array}{c}2261.7 \pm 678.5 \\
2,461.0 \\
1,177 \text { to } 3,029\end{array}$ & $\begin{array}{c}1108.5 \pm 203.7 \\
1,149.5^{c} \\
825 \text { to } 1,310\end{array}$ & $\begin{array}{c}1972.4 \pm 694.4 \\
2,028.0 \\
674 \text { to } 3,224\end{array}$ & $\begin{array}{c}1289.8 \pm 296.2 \\
1,330.0^{d} \\
639 \text { to } 1,738\end{array}$ \\
\hline $\begin{array}{l}\text { Serum IgA }(\mathrm{mg} / \mathrm{dL}) \\
\text { Mean } \pm \mathrm{SD} \\
\text { Median } \\
\text { Range }\end{array}$ & & $\begin{array}{c}345.7 \pm \\
211.6 \\
305.0 \\
128 \text { to } 1420\end{array}$ & $\begin{array}{c}394.1 \pm 319.9 \\
290.5 \\
147 \text { to } 1420\end{array}$ & $\begin{array}{c}319.9 \pm 120.8 \\
308.5 \\
128 \text { to } 584\end{array}$ & $\begin{array}{c}396.9 \pm 248.9 \\
343.0 \\
128 \text { to } 1,420\end{array}$ & $\begin{array}{c}258.5 \pm 68.9 \\
259.0 \\
147 \text { to } 419\end{array}$ & $\begin{array}{c}446.6 \pm 355.8 \\
337.0 \\
176 \text { to } 1,420\end{array}$ & $\begin{array}{c}236.8 \pm 60.3 \\
261.5 \\
147 \text { to } 277\end{array}$ & $\begin{array}{c}361.8 \pm 135.0 \\
353.0 \\
128 \text { to } 584\end{array}$ & $\begin{array}{c}265.2 \pm 72.2 \\
240.0 \\
175 \text { to } 419\end{array}$ \\
\hline $\begin{array}{l}\text { Serum } \\
\text { hyperviscosity (AU) } \\
\text { Mean } \pm \text { SD } \\
\text { Median } \\
\text { Range }\end{array}$ & & $\begin{array}{c}2.0 \pm 0.5 \\
1.9 \\
1.6 \text { to } 4.3\end{array}$ & $\begin{array}{c}2.2 \pm 0.6 \\
2.1 \\
1.7 \text { to } 4.3\end{array}$ & $\begin{array}{c}1.9 \pm 0.3 \\
1.8 \\
1.6 \text { to } 2.5\end{array}$ & $\begin{array}{c}2.2 \pm 0.5 \\
2.1 \\
1.7 \text { to } 4.3\end{array}$ & $\begin{array}{c}1.8 \pm 0.1 \\
1.8^{\mathrm{b}} \\
1.6 \text { to } 2.0\end{array}$ & $\begin{array}{c}2.3 \pm 0.7 \\
2.2 \\
1.7 \text { to } 4.3\end{array}$ & $\begin{array}{c}1.8 \pm 0.2 \\
1.7^{c} \\
1.7 \text { to } 2.0\end{array}$ & $\begin{array}{c}2.0 \pm 0.3^{*} \\
1.9 \\
1.7 \text { to } 2.5\end{array}$ & $\begin{array}{c}1.8 \pm 0.1 \\
1.8^{\mathrm{d}} \\
1.6 \text { to } 2.0\end{array}$ \\
\hline $\begin{array}{l}\mathrm{C} 3(\mathrm{mg} / \mathrm{dL}) \\
\text { Mean } \pm \mathrm{SD} \\
\text { Median } \\
\text { Range }\end{array}$ & & $\begin{array}{c}96.4 \pm 23.6 \\
92.6 \\
53 \text { to } 147\end{array}$ & $\begin{array}{c}92.1 \pm 24.5 \\
91.5 \\
53 \text { to } 135\end{array}$ & $\begin{array}{c}98.3 \pm 23.3 \\
92.9 \\
60 \text { to } 147\end{array}$ & $\begin{array}{c}88.5 \pm 22.3 \\
81.4 \\
53 \text { to } 143\end{array}$ & $\begin{array}{c}108.7 \pm 19.9 \\
105.8^{\mathrm{b}} \\
77 \text { to } 147\end{array}$ & $\begin{array}{c}88.7 \pm 26.5 \\
83.4 \\
53 \text { to } 135\end{array}$ & $\begin{array}{c}103.2 \pm 14.2 \\
99.0 \\
92 \text { to } 119\end{array}$ & $\begin{array}{c}88.4 \pm 20.4 \\
81.4 \\
60 \text { to } 143\end{array}$ & $\begin{array}{c}110.1 \pm 21.3 \\
106.4^{d} \\
77 \text { to } 147\end{array}$ \\
\hline
\end{tabular}


Table 1 Demographic and clinical characteristics of patients with primary Sj?ö?gren?'?s syndrome (Continued)

\begin{tabular}{|c|c|c|c|c|c|c|c|c|c|c|}
\hline $\begin{array}{l}\mathrm{C} 4(\mathrm{mg} / \mathrm{dL}) \\
\text { Mean } \pm \mathrm{SD} \\
\text { Median } \\
\text { Range }\end{array}$ & & $\begin{array}{c}19.8 \pm 6.8 \\
19.0 \\
2 \text { to } 33\end{array}$ & $\begin{array}{c}18.6 \pm 9.6 \\
19.1 \\
2 \text { to } 33\end{array}$ & $\begin{array}{c}20.3 \pm 5.3 \\
18.9 \\
11 \text { to } 33\end{array}$ & $\begin{array}{c}17.7 \pm 6.8 \\
18.6 \\
2 \text { to } 33\end{array}$ & $\begin{array}{c}23.6 \pm 5.4 \\
24.0^{c} \\
15 \text { to } 33\end{array}$ & $\begin{array}{c}16.8 \pm 10.2 \\
18.5 \\
2 \text { to } 33\end{array}$ & $\begin{array}{c}24.4 \pm 4.6 \\
26.0 \\
19 \text { to } 25\end{array}$ & $\begin{array}{c}18.3 \pm 4.0 \\
18.6 \\
11 \text { to } 51\end{array}$ & $\begin{array}{c}23.4 \pm 5.7 \\
24.0 \\
15 \text { to } 33\end{array}$ \\
\hline $\begin{array}{l}\text { Leucocytes (cells/ } \\
\mu \mathrm{L} \text { ) } \\
\text { Mean } \pm \mathrm{SD} \\
\text { Median } \\
\text { Range }\end{array}$ & $\begin{array}{c}6.4 \pm 1.3 \\
6.3 \\
4.7-8.5\end{array}$ & $\begin{array}{c}5.7 \pm 2.0 \\
5.5 \\
1.5 \text { to } 12.6\end{array}$ & $\begin{array}{c}5.6 \pm 2.7 \\
5.4 \\
1.5 \text { to } 12.6\end{array}$ & $\begin{array}{c}5.7 \pm 1.7 \\
5.7 \\
3.0 \text { to } 10.7\end{array}$ & $\begin{array}{c}5.1 \pm 1.6 \\
5.2 \\
1.5 \text { to } 8.2\end{array}$ & $\begin{array}{c}6.6 \pm 2.5 \\
6.2 \\
3.9 \text { to } 12.6\end{array}$ & $\begin{array}{c}4.8 \pm 1.9 \\
4.7 \\
1.5 \text { to } 8.1\end{array}$ & $\begin{array}{c}8.4 \pm 3.4 \\
7.8 \\
5.2 \text { to } 12.6\end{array}$ & $\begin{array}{c}5.4 \pm 1.3 \\
5.6 \\
3.0 \text { to } 8.2\end{array}$ & $\begin{array}{c}6.2 \pm 2.0 \\
6.0 \\
3.9 \text { to } 10.7\end{array}$ \\
\hline $\begin{array}{l}\text { Hemoglobin }(\mathrm{g} / \mathrm{dL}) \\
\text { Mean } \pm \mathrm{SD} \\
\text { Median } \\
\text { Range }\end{array}$ & $\begin{array}{c}14.9 \pm 0.8 \\
14.9 \\
13.3-16.5\end{array}$ & $\begin{array}{c}13.9 \pm 1.4 \\
14.1 \\
9.9 \text { to } 17.8\end{array}$ & $\begin{array}{c}14.4 \pm 1.3 \\
14.0 \\
12.7 \text { to } 17.8\end{array}$ & $\begin{array}{c}13.7 \pm 1.4 \\
\quad 14.1 \\
9.9 \text { to } 15.9\end{array}$ & $\begin{array}{c}13.9 \pm 1.1 \\
14.0 \\
12.1 \text { to } 15.9\end{array}$ & $\begin{array}{c}14.1 \pm 1.8 \\
14.5 \\
9.9 \text { to } 17.8\end{array}$ & $\begin{array}{c}13.9 \pm 0.7 \\
14.0 \\
12.7 \text { to } 15.0\end{array}$ & $\begin{array}{c}16.1 \pm 1.4 \\
15.8 c \\
14.9 \text { to } 17.8\end{array}$ & $\begin{array}{c}13.8 \pm 1.3 \\
14.1 \\
12.1 \text { to } 15.9\end{array}$ & $\begin{array}{c}13.6 \pm 1.5 \\
14.3 \\
9.9 \text { to } 15.1\end{array}$ \\
\hline 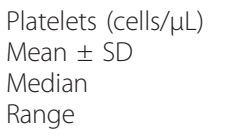 & $\begin{array}{c}264.2 \pm \\
51.1 \\
225.9 \\
172-331\end{array}$ & $\begin{array}{c}229.1 \pm 68.1 \\
229.5 \\
73 \text { to } 367\end{array}$ & $\begin{array}{c}233.7 \pm 95.6 \\
195.0 \\
73 \text { to } 367\end{array}$ & $\begin{array}{c}231.9 \pm 50.0 \\
231.0 \\
149 \text { to } 357\end{array}$ & $\begin{array}{c}223.9 \pm 68.9 \\
222.0 \\
82 \text { to } 367\end{array}$ & $\begin{array}{c}228.1 \pm 69.3 \\
221.0 \\
73 \text { to } 357\end{array}$ & $\begin{array}{c}240.2 \pm 98.2 \\
234.5 \\
82 \text { to } 367\end{array}$ & $\begin{array}{c}153.0 \pm 56.8 \\
172.0^{c} \\
73 \text { to } 195\end{array}$ & $\begin{array}{c}212.4 \pm 36.7 \\
222.0 \\
154 \text { to } 279\end{array}$ & $\begin{array}{c}249.5 \pm 57.5 \\
245.5 \\
149 \text { to } 357\end{array}$ \\
\hline $\begin{array}{l}\text { Lymphocytes (\%) } \\
\text { Mean } \pm \text { SD } \\
\text { Median } \\
\text { Range }\end{array}$ & $\begin{array}{c}31.1 \pm 6.2 \\
32.0 \\
20.3-39.7\end{array}$ & $\begin{array}{c}30.0 \pm 10.8 \\
28.0 \\
9.0 \text { to } 58.0\end{array}$ & $\begin{array}{c}29.9 \pm 12.5 \\
29.3 \\
12.9 \text { to } 58\end{array}$ & $\begin{array}{c}30.0 \pm 9.9 \\
27.5 \\
9.0 \text { to } 52.3\end{array}$ & $\begin{array}{c}31.1 \pm 10.2 \\
29.3 \\
13.1 \text { to } 58.0\end{array}$ & $\begin{array}{c}27.7 \pm 12.3 \\
26.5 \\
9.0 \text { to } 52.3\end{array}$ & $\begin{array}{c}33.5 \pm 12.5 \\
29.9 \\
13.1 \text { to } 58.0\end{array}$ & $\begin{array}{c}19.1 \pm 7.3 \\
18.2^{c} \\
12.9 \text { to } 27.0\end{array}$ & $\begin{array}{c}29.5 \pm 8.1 \\
28.5 \\
18.2 \text { to } 48.0\end{array}$ & $\begin{array}{c}30.2 \pm 12.5 \\
27.1 \\
9.0 \text { to } 52.3\end{array}$ \\
\hline $\begin{array}{l}\text { Monocytes (\%) } \\
\text { Mean } \pm \text { SD } \\
\text { Median } \\
\text { Range }\end{array}$ & & $\begin{array}{c}8.0 \pm 3.6 \\
7.2 \\
3 \text { to } 27\end{array}$ & $\begin{array}{c}8.7 \pm 5.2 \\
7.1 \\
5 \text { to } 27\end{array}$ & $\begin{array}{c}7.6 \pm 2.4 \\
7.2 \\
3 \text { to } 14\end{array}$ & $\begin{array}{c}8.3 \pm 4.2 \\
7.8 \\
5 \text { to } 27\end{array}$ & $\begin{array}{c}7.4 \pm 2.1 \\
6.7 \\
4 \text { to } 12\end{array}$ & $\begin{array}{c}8.5 \pm 6.0 \\
7.1 \\
5 \text { to } 27\end{array}$ & $\begin{array}{c}7.9 \pm 1.7 \\
8.0 \\
6 \text { to } 10\end{array}$ & $\begin{array}{c}8.2 \pm 2.4 \\
8.0 \\
5 \text { to } 14\end{array}$ & $\begin{array}{c}7.2 \pm 2.3 \\
6.7 \\
4 \text { to } 12\end{array}$ \\
\hline $\begin{array}{l}\text { Polymorphonuclear } \\
\text { cells(\%) } \\
\text { Mean } \pm \text { SD } \\
\text { Median } \\
\text { Range }\end{array}$ & & $\begin{array}{c}58.9 \pm 11.8 \\
61.9 \\
15.0 \text { to } 79.5\end{array}$ & $\begin{array}{c}59.5 \pm 15.2 \\
63.0 \\
15.0 \text { to } 79.5\end{array}$ & $\begin{array}{c}58.7 \pm 9.8 \\
61.7 \\
38.8 \text { to } 76.0\end{array}$ & $\begin{array}{c}57.3 \pm 11.9 \\
60.4 \\
15.0 \text { to } 78.1\end{array}$ & $\begin{array}{c}62.1 \pm 12.0 \\
64.4 \\
38.8 \text { to } 79.5\end{array}$ & $\begin{array}{c}56.0 \pm 16.2 \\
60.4 \\
15.0-78.1\end{array}$ & $\begin{array}{c}70.9 \pm 6.9 \\
70.6 \\
63.0 \text { to } 79.5\end{array}$ & $\begin{array}{c}58.3 \pm 8.0 \\
60.4 \\
40.0 \text { to } 68.8\end{array}$ & $\begin{array}{c}59.6 \pm 12.2 \\
63.5 \\
38.8 \text { to } 76.0\end{array}$ \\
\hline
\end{tabular}




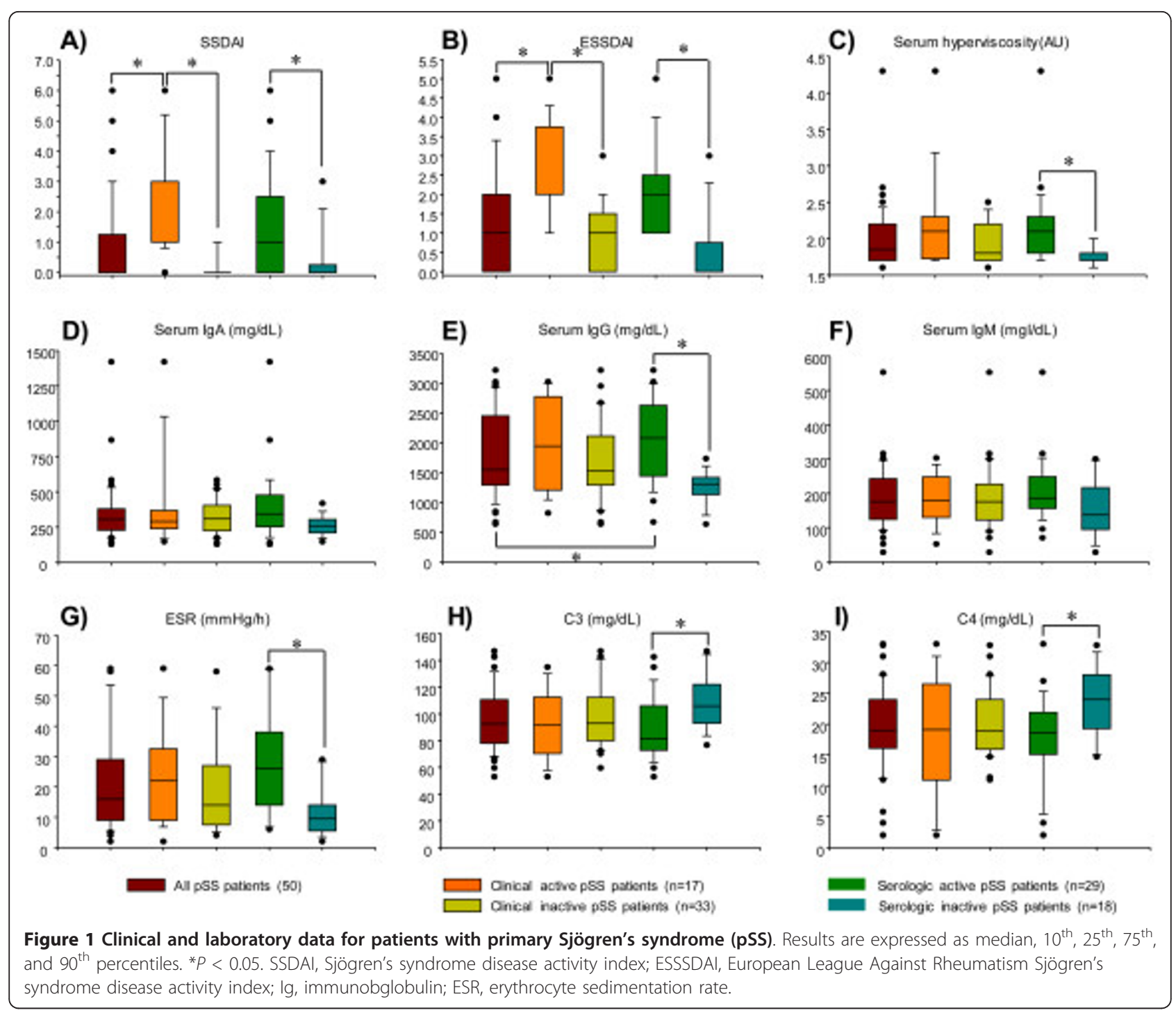

(Table 2; Figure $4 \mathrm{H}$ ). The percentage of CD $19^{+} / \mathrm{CD} 38^{\text {hi }}$ / CD24 $4^{\text {hi }} / \mathrm{CXCR}^{+} / \mathrm{IL}^{-10^{+}}$cells was similar in pSS patients and the healthy control group (Table 2; Figure 4I). The cell frequency of $\mathrm{CD} 19^{+} / \mathrm{CD} 38^{\mathrm{hi}} / \mathrm{CD} 24^{\mathrm{hi}} / \mathrm{CXCR} 7^{+} / \mathrm{IL}-10^{+}$ was higher in pSS patients without clinical activity when compared with pSS patients with clinically active disease and healthy controls $(P<0.05)$ (Table 2 ; Figure $4 \mathrm{~J})$. It is important to note that the results are expressed as the relative percentage obtained from $\mathrm{CD} 19^{+} / \mathrm{CD}_{3} 8^{\mathrm{hi}} /$ CD24 $4^{\text {hi }} / \mathrm{IL}-10^{+}$B cells (Figure $2 \mathrm{~A}$, red bars).

\section{Percentage of $\mathrm{IDO}^{+}$plasmacytoid dendritic cells in patients with pSS}

A subpopulation of plasmacytoid DCs derived from monocytes expressing $\mathrm{CD} 123^{\mathrm{hi}} / \mathrm{CCR}^{+} / \mathrm{IDO}^{+}$that are responsible for mediating the suppression of effector $\mathrm{T}$ cells has recently been described. The frequency of these cells in peripheral blood was higher in all subgroups of patients with pSS when compared with the control group $(P<0.05)$ (Table 2; Figure 5I).

\section{Frequency of Foxp $3^{+}$regulatory $\mathrm{T}$ cells circulating in patients with pSS}

We performed analyses to determine the various subpopulations of lymphocytes that regulate the adaptive immune response and induce peripheral tolerance of $\mathrm{CD}^{+} / \mathrm{CD} 25^{\mathrm{hi}} / \mathrm{Foxp}^{+}$and $\mathrm{CD}^{+} / \mathrm{CD} 28^{-} /$Foxp $^{+}$cell subpopulations. There were no statistically significant differences in the frequency of $\mathrm{CD} 4^{+} / \mathrm{CD} 25^{\mathrm{hi}} / \mathrm{Foxp}^{+}$cells (Table 2; Figure 5J). Nevertheless, a lower percentage of $\mathrm{CD}^{+} / \mathrm{CD}^{2} 8^{-} /$Foxp $^{+}$cells was observed in pSS patients without clinically active disease but with serologic activity compared with the healthy control group $(P<0.05)$ (Table 2; Figure 5K). 
Table 2 IL-10-producing B cells, IDO-expressing dendritic cells and forkhead box protein 3-expressing regulatory T peripheral cells

\begin{tabular}{|c|c|c|c|c|c|c|c|c|c|c|}
\hline Variable & $\begin{array}{l}\text { Control } \\
(n=25)\end{array}$ & $\begin{array}{c}\text { All } \\
\text { pSS } \\
\text { patients } \\
(n=50)\end{array}$ & $\begin{array}{l}\text { Clinically } \\
\text { active } \\
\text { pSS } \\
\text { patients } \\
(n=17)\end{array}$ & $\begin{array}{c}\text { Clinically } \\
\text { inactive } \\
\text { pSS patients } \\
(n=33)\end{array}$ & $\begin{array}{l}\text { Serologically } \\
\text { active } \\
\text { pSS patients } \\
(n=29)\end{array}$ & $\begin{array}{l}\text { Serologically } \\
\text { inactive } \\
\text { pSS patients } \\
(n=18)\end{array}$ & $\begin{array}{l}\text { Clinically and } \\
\text { serologically active } \\
\text { pSS patients } \\
(n=12)\end{array}$ & $\begin{array}{l}\text { Clinically active } \\
\text { and serologically } \\
\text { inactive } \\
\text { pSS patients } \\
(n=4)\end{array}$ & $\begin{array}{l}\text { Clinically inactive and } \\
\text { serologically active pSS } \\
\text { patients } \\
(n=17)\end{array}$ & $\begin{array}{c}\text { Clinically } \\
\text { and } \\
\text { serologically } \\
\text { inactive } \\
\text { pSS patients } \\
(n=14)\end{array}$ \\
\hline $\begin{array}{l}\text { CD19+ }^{+} \text {B cells from } \\
\text { PBMCs (\%) } \\
\text { Mean } \pm \text { SEM } \\
\text { Median } \\
\text { Range }\end{array}$ & $\begin{array}{c}10.7 \pm 0.7 \\
10.5 \\
5.2 \text { to } 19.3\end{array}$ & $\begin{array}{c}11.0 \pm 1.0 \\
10.5 \\
0.4 \text { to } 30.0\end{array}$ & $\begin{array}{c}11.0 \pm 1.6 \\
10.7 \\
1.6 \text { to } \\
27.3\end{array}$ & $\begin{array}{c}11.0 \pm 1.2 \\
10.1 \\
0.4 \text { to } 30.0\end{array}$ & $\begin{array}{c}11.2 \pm 1.3 \\
9.4 \\
0.4 \text { to } 30.0\end{array}$ & $\begin{array}{c}13.0 \pm 1.6 \\
11.9 \\
1.0 \text { to } 27.3\end{array}$ & $\begin{array}{c}9.8 \pm 2.1 \\
10.0 \\
1.6 \text { to } 27.3\end{array}$ & $\begin{array}{c}15.6 \pm 1.2 \\
14.7 \\
14.0 \text { to } 19.0\end{array}$ & $\begin{array}{c}10.5 \pm 1.7 \\
8.4 \\
0.4 \text { to } 30.0\end{array}$ & $\begin{array}{c}12.2 \pm 2.0 \\
10.5 \\
1.0 \text { to } 27.3\end{array}$ \\
\hline \multicolumn{11}{|l|}{$\begin{array}{l}\text { IL-10-producing B } \\
\text { cells (\%) }\end{array}$} \\
\hline $\begin{array}{l}\mathrm{CD} 19^{+} / \mathrm{CD} 8^{\mathrm{hi}} \\
\text { Mean } \pm \text { SEM } \\
\text { Median } \\
\text { Range }\end{array}$ & $\begin{array}{c}1.6 \pm 0.2 \\
1.4 \\
0.8 \text { to } 4.5\end{array}$ & $\begin{array}{c}3.5 \pm 0.3 \\
2.9 \\
0.3 \text { to } 9.0\end{array}$ & $\begin{array}{c}3.8 \pm 0.7 \\
2.9 \\
0.3 \text { to } 9.0\end{array}$ & $\begin{array}{c}3.4 \pm 0.3 \\
2.9 \\
1.2 \text { to } 8.8\end{array}$ & $\begin{array}{c}3.8 \pm 0.5 \\
2.9 \\
0.3 \text { to } 9.0\end{array}$ & $\begin{array}{c}3.0 \pm 0.3 \\
2.8 \\
1.2 \text { to } 5.8\end{array}$ & $\begin{array}{c}4.0 \pm 0.9 \\
3.4 \\
0.3 \text { to } 9.0\end{array}$ & $\begin{array}{c}2.3 \pm 0.5 \\
2.1 \\
1.3 \text { to } 3.6\end{array}$ & $\begin{array}{c}3.6 \pm 0.5 \\
2.8 \\
1.4 \text { to } 8.8\end{array}$ & $\begin{array}{c}3.3 \pm 0.3 \\
3.0 \\
1.2 \text { to } 5.8\end{array}$ \\
\hline $\begin{array}{l}\text { CD } 19^{+} / \text {CD 38 }{ }^{\text {hi }} / \text { LL-10 } \\
+ \\
\text { Mean } \pm \text { SEM } \\
\text { Median } \\
\text { Range }\end{array}$ & $\begin{array}{c}0.13 \pm 0.02 \\
0.10 \\
0.03 \text { to } 0.40\end{array}$ & $\begin{array}{c}0.16 \pm 0.02 \\
0.12 \\
0.03 \text { to } 0.91\end{array}$ & $\begin{array}{l}0.18 \pm \\
0.05 \\
0.14 \\
0.03 \text { to } \\
0.91\end{array}$ & $\begin{array}{c}0.15 \pm 0.02 \\
0.11 \\
0.03 \text { to } 0.43\end{array}$ & $\begin{array}{c}0.17 \pm 0.03 \\
0.12 \\
0.03 \text { to } 0.91\end{array}$ & $\begin{array}{c}0.14 \pm 0.03 \\
0.08 \\
0.03 \text { to } 0.35\end{array}$ & $\begin{array}{c}0.21 \pm 0.07 \\
0.25 \\
0.04 \text { to } 0.91\end{array}$ & $\begin{array}{c}0.09 \pm 0.05 \\
0.07 \\
0.03 \text { to } 0.21\end{array}$ & $\begin{array}{c}0.14 \pm 0.03 \\
0.10 \\
0.03 \text { to } 0.43\end{array}$ & $\begin{array}{c}0.16 \pm 0.03 \\
0.13 \\
0.03 \text { to } 0.35\end{array}$ \\
\hline $\begin{array}{l}\mathrm{CD} 19^{+} / \mathrm{CD} 38^{\mathrm{hi}} / \mathrm{lgA} \\
+/ \mathrm{LL}-10^{+} \\
\text {Mean } \pm \mathrm{SEM} \\
\text { Median } \\
\text { Range }\end{array}$ & $\begin{array}{c}65.8 \pm 1.5 \\
66.4 \\
51.3 \text { to } 78.6\end{array}$ & $\begin{array}{c}75.7 \pm 1.9 \\
77.3^{\mathrm{e}} \\
36.4 \text { to } 94.6\end{array}$ & $\begin{array}{l}75.2 \pm 3.6 \\
74.6 \\
45.8 \text { to } \\
94.6\end{array}$ & $\begin{array}{c}76.3 \pm 2.6 \\
80.4^{\mathrm{e}} \\
36.4 \text { to } 93.8\end{array}$ & $\begin{array}{c}75.3 \pm 2.6 \\
78.1^{\mathrm{e}} \\
36.4 \text { to } 94.6\end{array}$ & $\begin{array}{c}75.3 \pm 3.7 \\
75.7^{e} \\
43.3 \text { to } 93.8\end{array}$ & $\begin{array}{c}72.9 \pm 4.5 \\
\quad 74.4 \\
45.8 \text { to } 94.6\end{array}$ & $\begin{array}{c}77.7 \pm 3.4 \\
75.7 \\
73.0 \text { to } 84.4\end{array}$ & $\begin{array}{c}76.9 \pm 3.2 \\
80.0^{\mathrm{e}} \\
36.4 \text { to } 89.8\end{array}$ & $\begin{array}{c}74.5 \pm 5.0 \\
78.8 \\
43.3 \text { to } 93.8\end{array}$ \\
\hline $\begin{array}{l}\mathrm{CD} 19^{+} / \mathrm{CD} 38^{\mathrm{hi}} / \mathrm{lgG} \\
+/ / \mathrm{L}-10^{+} \\
\text {Mean } \pm \mathrm{SEM} \\
\text { Median } \\
\text { Range }\end{array}$ & $\begin{array}{c}55.3 \pm 2.8 \\
60.8 \\
26.7 \text { to } 79.6\end{array}$ & $\begin{array}{c}42.8 \pm 2.0 \\
41.7^{\mathrm{e}} \\
22.2 \text { to } 74.2\end{array}$ & $\begin{array}{l}38.6 \pm 3.7 \\
32.9^{\mathrm{e}} \\
22.2 \text { to } \\
65.2\end{array}$ & $\begin{array}{c}48.1 \pm 2.0 \\
48.6^{\text {ae }} \\
31.4 \text { to } 74.2\end{array}$ & $\begin{array}{c}45.3 \pm 2.5 \\
41.7^{\mathrm{e}} \\
23.2 \text { to } 74.2\end{array}$ & $\begin{array}{c}45.2 \pm 3.2 \\
46.0 \\
22.2 \text { to } 59.3\end{array}$ & $\begin{array}{c}39.3 \pm 4.2 \\
32.9^{e} \\
23.2 \text { to } 65.2\end{array}$ & $\begin{array}{c}41.2 \pm 10.7 \\
42.1 \\
22.2 \text { to } 59.3\end{array}$ & $\begin{array}{c}49.2 \pm 2.9 \\
49.5 \\
31.4 \text { to } 74.2\end{array}$ & $\begin{array}{c}46.6 \pm 3.0 \\
46.2 \\
33.3 \text { to } 57.8\end{array}$ \\
\hline $\begin{array}{l}\text { CD } 19^{+} / \text {CD } 38^{\text {hi }} / \mathrm{lgM} \\
+/ / \mathrm{L}-10^{+} \\
\text {Mean } \pm \text { SEM } \\
\text { Median } \\
\text { Range }\end{array}$ & $\begin{array}{c}21.7 \pm 1.3 \\
21.1 \\
10.7 \text { to } 35.0\end{array}$ & $\begin{array}{c}22.8 \pm 1.5 \\
20.2 \\
3.0 \text { to } 54.0\end{array}$ & $\begin{array}{l}20.2 \pm 2.4 \\
15.8 \\
10.0 \text { to } \\
38.7\end{array}$ & $\begin{array}{c}25.1 \pm 2.2 \\
22.7 \\
3.0 \text { to } 54.0\end{array}$ & $\begin{array}{c}22.8 \pm 2.1 \\
21.1 \\
3.0 \text { to } 52.2\end{array}$ & $\begin{array}{c}25.4 \pm 3.2 \\
23.1 \\
12.1 \text { to } 54.0\end{array}$ & $\begin{array}{c}21.7 \pm 3.1 \\
22.6 \\
10.2 \text { to } 38.7\end{array}$ & $\begin{array}{c}16.4 \pm 1.7 \\
15.8 \\
13.8 \text { to } 19.5\end{array}$ & $\begin{array}{c}23.5 \pm 2.8 \\
20.2 \\
3.0 \text { to } 52.2\end{array}$ & $\begin{array}{c}28.2 \pm 3.8 \\
28.2 \\
12.1 \text { to } 54.0\end{array}$ \\
\hline $\begin{array}{l}\mathrm{CD}_{1} 9^{+} / \mathrm{CD} 8^{\text {hi }} / \\
\mathrm{CD} 24^{4_{i}} \\
\text { Mean } \pm \mathrm{SEM} \\
\text { Median } \\
\text { Range }\end{array}$ & $\begin{array}{c}0.7 \pm 0.1 \\
0.5 \\
0.2 \text { to } 2.9\end{array}$ & $\begin{array}{c}0.6 \pm 0.1 \\
0.5 \\
0.1 \text { to } 1.6\end{array}$ & $\begin{array}{c}1.7 \pm 0.4 \\
\quad 1.1 \\
0.3 \text { to } 4.7\end{array}$ & $\begin{array}{c}2.2 \pm 0.3 \\
2.0 \\
0.4 \text { to } 7.7\end{array}$ & $\begin{array}{c}2.2 \pm 0.3 \\
1.7 \\
0.3 \text { to } 8.8\end{array}$ & $\begin{array}{c}1.8 \pm 0.2 \\
1.7 \\
0.4 \text { to } 3.7\end{array}$ & $\begin{array}{c}1.9 \pm 0.5 \\
1.0 \\
0.3 \text { to } 4.7\end{array}$ & $\begin{array}{l}0.8 \pm 0.2 \\
0.8 \\
0.4 \text { to } 1.3\end{array}$ & $\begin{array}{c}2.4 \pm 0.4 \\
2.0 \\
0.5 \text { to } 7.7\end{array}$ & $\begin{array}{c}2.1 \pm 0.3 \\
2.2 \\
0.5 \text { to } 3.7\end{array}$ \\
\hline $\begin{array}{l}\mathrm{CD} 19^{+} / \mathrm{CD} 38^{\mathrm{hi}} / \\
\mathrm{CD} 24^{\mathrm{hi}} / / \mathrm{LL}-10^{+} \\
\text {Mean } \pm \text { SEM } \\
\text { Median }\end{array}$ & $\begin{array}{c}0.20 \pm 0.02 \\
0.19 \\
0.06 \text { to } 0.44\end{array}$ & $\begin{array}{c}0.55 \pm 0.05 \\
0.46{ }^{\mathrm{e}} \\
0.12 \text { to } 1.59\end{array}$ & $\begin{array}{l}0.38 \pm \\
0.05 \\
0.37 \\
0.12 \text { to }\end{array}$ & $\begin{array}{c}0.63 \pm 0.06 \\
0.56^{\mathrm{e}} \\
0.13 \text { to } 1.59\end{array}$ & $\begin{array}{c}0.57 \pm 0.07^{*} \\
0.47^{\mathrm{e}} \\
0.12 \text { to } 1.59\end{array}$ & $\begin{array}{c}0.53 \pm 0.07 \\
0.46^{\mathrm{e}} \\
0.15 \text { to } 1.07\end{array}$ & $\begin{array}{c}0.40 \pm 0.06 \\
0.40 \\
0.12 \text { to } 0.87\end{array}$ & $\begin{array}{c}0.32 \pm 0.06 \\
0.32 \\
0.18 \text { to } 0.47\end{array}$ & $\begin{array}{c}0.69 \pm 0.09 \\
0.65^{\mathrm{e}} \\
0.13 \text { to } 1.59\end{array}$ & $\begin{array}{c}0.59 \pm 0.08 \\
0.52^{\mathrm{e}} \\
0.15 \text { to } 1.07\end{array}$ \\
\hline
\end{tabular}


Table 2 IL-10-producing B cells, IDO-expressing dendritic cells and forkhead box protein 3-expressing regulatory $\mathrm{T}$ peripheral cells (Continued)

\begin{tabular}{|c|c|c|c|c|c|c|c|c|c|c|}
\hline $\begin{array}{l}\text { CD } 19^{+} / \mathrm{CD} 8^{\text {hi }} / / \\
\text { CD24 } 4^{\text {hi }} / \mathrm{CD}^{+} / / \mathrm{L}-10^{+} \\
\text {Mean } \pm \mathrm{SEM} \\
\text { Median } \\
\text { Range }\end{array}$ & $\begin{array}{c}17.7 \pm 1.3 \\
15.5 \\
8.6 \text { to } 32.4\end{array}$ & $\begin{array}{c}20.2 \pm 1.4 \\
20.0 \\
2.8 \text { to } 45.2\end{array}$ & $\begin{array}{l}11.4 \pm 1.4 \\
10.9^{\mathrm{e}} \\
2.8 \text { to } \\
22.8\end{array}$ & $\begin{array}{c}24.8 \pm 1.4 \\
23.7^{\mathrm{a}} \mathrm{e} \\
8.0 \text { to } 45.2\end{array}$ & $\begin{array}{c}18.8 \pm 1.7 \\
18.8 \\
2.8 \text { to } 38.7\end{array}$ & $\begin{array}{c}22.9 \pm 2.5 \\
23.5 \\
7.1 \text { to } 45.2\end{array}$ & $\begin{array}{c}11.9 \pm 1.8 \\
11.8 \mathrm{e}^{-} \\
2.8 \text { to } 22.8\end{array}$ & $\begin{array}{c}11.0 \pm 2.3 \\
10.1 \\
7.1 \text { to } 16.6\end{array}$ & $\begin{array}{c}23.1 \pm 2.0 \\
22.0 \\
8.0 \text { to } 38.7\end{array}$ & $\begin{array}{c}27.1 \pm 2.2 \\
24.2^{\mathrm{e}} \\
16.2 \text { to } 45.2\end{array}$ \\
\hline $\begin{array}{l}\text { CD } 19^{+} / \mathrm{CD} 38^{\text {hi }} / \\
\text { CD2 } 24^{\text {hi}} / \mathrm{CD}^{+} 0^{+} / \mathrm{LL}-10 \\
+ \\
\text { Mean } \pm \text { SEM } \\
\text { Median } \\
\text { Range }\end{array}$ & $\begin{array}{c}15.8 \pm 1.3 \\
16.7 \\
3.3 \text { to } 27.0\end{array}$ & $\begin{array}{c}22.5 \pm 1.6 \\
22.9^{\mathrm{e}} \\
4.4 \text { to } 42.9\end{array}$ & $\begin{array}{c}16.9 \pm 2.8 \\
13.8 \\
4.4 \text { to } \\
39.7\end{array}$ & $\begin{array}{c}25.5 \pm 1.7 \\
25.6^{\text {ae }} \\
6.6 \text { to } 42.9\end{array}$ & $\begin{array}{c}19.5 \pm 2.0 \\
20.0 \\
4.4 \text { to } 39.7\end{array}$ & $\begin{array}{c}27.5 \pm 2.2 \\
26.3^{\text {be }} \\
10.3 \text { to } 42.9\end{array}$ & $\begin{array}{c}16.1 \pm 3.9 \\
10.7 \\
4.4 \text { to } 39.7\end{array}$ & $\begin{array}{c}19.6 \pm 3.9 \\
19.8 \\
10.3 \text { to } 28.6\end{array}$ & $\begin{array}{c}21.9 \pm 2.1 \\
22.9^{\mathrm{e}} \\
6.6 \text { to } 33.3\end{array}$ & $\begin{array}{c}30.1 \pm 2.1 \\
29.8^{\text {de }} \\
18.2 \text { to } 42.9\end{array}$ \\
\hline $\begin{array}{l}\text { CD19+/CD38 } 8^{\text {hi }} \\
\text { CD24hi/CD20 } / / \text { L-10 } \\
+ \\
\text { Mean } \pm \text { SEM } \\
\text { Median } \\
\text { Range }\end{array}$ & $\begin{array}{c}20.3 \pm 1.6 \\
17.5 \\
11.1 \text { to } 37.2\end{array}$ & $\begin{array}{c}29.4 \pm 2.1 \\
27.9^{\mathrm{e}} \\
10.2 \text { to } 66.7\end{array}$ & $\begin{array}{c}23.8 \pm 3.2 \\
16.2 \\
10.2 \text { to } \\
46.2\end{array}$ & $\begin{array}{c}32.5 \pm 2.6 \\
30.9^{\text {ae }} \\
12.6 \text { to } 66.7\end{array}$ & $\begin{array}{c}27.9 \pm 2.5 \\
23.8 \\
12.5 \text { to } 54.8\end{array}$ & $\begin{array}{c}28.5 \pm 3.6 \\
26.6 \\
10.2 \text { to } 66.7\end{array}$ & $\begin{array}{c}23.8 \pm 3.5 \\
16.5 \\
12.5 \text { to } 45.5\end{array}$ & $\begin{array}{c}18.4 \pm 7.2 \\
11.6 \\
10.2 \text { to } 40.0\end{array}$ & $\begin{array}{c}30.7 \pm 3.3 \\
33.0^{\mathrm{e}} \\
12.6 \text { to } 54.8\end{array}$ & $\begin{array}{c}31.2 \pm 3.8 \\
27.3^{\mathrm{e}} \\
16.2 \text { to } 66.7\end{array}$ \\
\hline $\begin{array}{l}\text { CD19 } 9^{+} / \mathrm{CD}_{3} 8^{\mathrm{hi}} / \\
\mathrm{CD} 24^{\mathrm{hi}} / \mathrm{CD}^{+} 7^{+} / \mathrm{LL}-10 \\
+ \\
\text { Mean } \pm \text { SEM } \\
\text { Median } \\
\text { Range }\end{array}$ & $\begin{array}{c}35.4 \pm 2.1 \\
34.0 \\
21.5 \text { to } 54.5\end{array}$ & $\begin{array}{c}38.8 \pm 1.8 \\
41.0 \\
11.3 \text { to } 68.5\end{array}$ & $\begin{array}{c}37.0 \pm 3.0 \\
39.6 \\
11.5 \text { to } \\
61.8\end{array}$ & $\begin{array}{c}39.7 \pm 2.3 \\
41.0 \\
11.3 \text { to } 68.5\end{array}$ & $\begin{array}{c}40.1 \pm 2.4 \\
41.5 \\
11.5 \text { to } 68.5\end{array}$ & $\begin{array}{c}36.9 \pm 2.7 \\
37.9 \\
11.3 \text { to } 52.5\end{array}$ & $\begin{array}{c}37.5 \pm 3.7 \\
38.1 \\
11.5-61.8\end{array}$ & $\begin{array}{c}41.5 \pm 1.8 \\
43.0 \\
37.9 \text { to } 43.6\end{array}$ & $\begin{array}{c}42.0 \pm 3.2 \\
42.4 \\
18.4 \text { to } 68.5\end{array}$ & $\begin{array}{c}35.6 \pm 3.2 \\
35.0 \\
11.3 \text { to } 52.5\end{array}$ \\
\hline $\begin{array}{l}\text { CD } 19^{+} / \mathrm{CD}_{3} 8^{\mathrm{hi}} / \\
\mathrm{CD} 24^{\mathrm{hi}} / \mathrm{CD} 27^{-} / \mathrm{LL}-10 \\
+ \\
\text { Mean } \pm \mathrm{SEM} \\
\text { Median } \\
\text { Range }\end{array}$ & $\begin{array}{c}11.3 \pm 1.8 \\
7.8 \\
0.0 \text { to } 32.6\end{array}$ & $\begin{array}{c}23.9 \pm 1.8 \\
20.7^{e} \\
5.5 \text { to } 52.7\end{array}$ & $\begin{array}{c}25.8 \pm 3.8 \\
22.4^{\mathrm{e}} \\
5.5 \text { to } \\
52.7\end{array}$ & $\begin{array}{c}23.0 \pm 1.9 \\
20.2^{\mathrm{e}} \\
7.4 \text { to } 49.5\end{array}$ & $\begin{array}{c}26.1 \pm 2.5 \\
21.7^{\mathrm{e}} \\
5.5 \text { to } 52.7\end{array}$ & $\begin{array}{c}20.5 \pm 2.5 \\
17.9^{\mathrm{e}} \\
7.4 \text { to } 41.7\end{array}$ & $\begin{array}{c}27.8 \pm 4.9 \\
28.2^{\mathrm{e}} \\
5.5 \text { to } 52.7\end{array}$ & $\begin{array}{c}21.5 \pm 0.94 \\
21.7 \\
19.8 \text { to } 23.0\end{array}$ & $\begin{array}{c}25.0 \pm 2.6 \\
20.7^{\mathrm{e}} \\
9.8 \text { to } 49.5\end{array}$ & $\begin{array}{c}20.7 \pm 2.9 \\
14.6^{\mathrm{e}} \\
7.4 \text { to } 41.7\end{array}$ \\
\hline $\begin{array}{l}\text { CD19+/CD38 } 8^{\text {hi }} / \\
\text { CD24 } \\
10^{+} / \text {CXCR4 } / / L- \\
\text { Mean } \pm \text { SEM } \\
\text { Median } \\
\text { Range }\end{array}$ & $\begin{array}{c}28.3 \pm 1.3 \\
27.3 \\
19.6 \text { to } 43.2\end{array}$ & $\begin{array}{c}26.6 \pm 1.5 \\
27.0 \\
9.6 \text { to } 46.1\end{array}$ & $\begin{array}{c}23.0 \pm 3.2 \\
15.1 \\
9.6 \text { to } \\
46.1\end{array}$ & $\begin{array}{c}28.6 \pm 1.4 \\
28.9 \\
16.0 \text { to } 44.4\end{array}$ & $\begin{array}{c}25.4 \pm 1.9 \\
24.5 \\
12.5 \text { to } 46.1\end{array}$ & $\begin{array}{c}28.0 \pm 2.6 \\
28.1 \\
9.6 \text { to } 44.4\end{array}$ & $\begin{array}{c}21.8 \pm 3.6 \\
15.0 \\
12.5 \text { to } 46.1\end{array}$ & $\begin{array}{c}28.0 \pm 9.1 \\
29.0 \\
9.6 \text { to } 44.4\end{array}$ & $\begin{array}{c}28.1 \pm 1.8 \\
28.5 \\
16.0 \text { to } 43.2\end{array}$ & $\begin{array}{c}28.1 \pm 2.1 \\
28.5 \\
17.2 \text { to } 44.4\end{array}$ \\
\hline $\begin{array}{l}\mathrm{CD} 19^{+} / \mathrm{CD} 8^{\mathrm{hi}} / \\
\mathrm{CD} 24^{\mathrm{hi}} / \mathrm{CXCR} 7^{+} / / \mathrm{L}- \\
10^{+} \\
\text {Mean } \pm \mathrm{SEM} \\
\text { Median } \\
\text { Range }\end{array}$ & $\begin{array}{c}20.6 \pm 1.3 \\
18.7 \\
12.3 \text { to } 33.1\end{array}$ & $\begin{array}{c}25.9 \pm 2.3 \\
22.5 \\
5.6 \text { to } 85.7\end{array}$ & $\begin{array}{c}18.2 \pm 2.5 \\
17.3 \\
5.6 \text { to } \\
34.62\end{array}$ & $\begin{array}{c}29.5 \pm 2.9 \\
26.1^{\text {ae }} \\
7.3 \text { to } 85.7\end{array}$ & $\begin{array}{c}24.3 \pm 3.1 \\
20.3 \\
5.6 \text { to } 85.7\end{array}$ & $\begin{array}{c}27.2 \pm 3.0 \\
27.2 \\
10.8 \text { to } 50.0\end{array}$ & $\begin{array}{c}17.4 \pm 2.6 \\
17.4 \\
5.6 \text { to } 33.6\end{array}$ & $\begin{array}{c}20.9 \pm 7.1 \\
17.2 \\
10.8 \text { to } 34.6\end{array}$ & $\begin{array}{c}28.8 \pm 4.5 \\
23.0 \\
7.3 \text { to } 85.7\end{array}$ & $\begin{array}{c}27.9 \pm 3.2 \\
27.2 \\
17.1 \text { to } 50.0\end{array}$ \\
\hline \multicolumn{11}{|l|}{ pDC IDO ${ }^{+}(\%)$} \\
\hline $\begin{array}{l}\mathrm{CCR}^{+} \\
\text {Mean } \pm \text { SEM } \\
\text { Median } \\
\text { Range }\end{array}$ & $\begin{array}{c}15.3 \pm 0.9 \\
16.5 \\
8.7 \text { to } 21.8\end{array}$ & $\begin{array}{c}16.7 \pm 0.8 \\
15.6 \\
8.6 \text { to } 31.1\end{array}$ & $\begin{array}{l}15.2 \pm 1.1 \\
15.4 \\
8.6 \text { to } \\
24.7\end{array}$ & $\begin{array}{c}17.5 \pm 1.1 \\
16.1 \\
9.2 \text { to } 31.1\end{array}$ & $\begin{array}{c}16.1 \pm 1.0 \\
15.5 \\
8.6 \text { to } 28.7\end{array}$ & $\begin{array}{c}18.4 \pm 1.6 \\
17.8 \\
9.5 \text { to } 31.1\end{array}$ & $\begin{array}{c}14.4 \pm 1.3 \\
14.3 \\
8.6 \text { to } 24.6\end{array}$ & $\begin{array}{c}17.3 \pm 2.8 \\
19.0 \\
9.5 \text { to } 21.1\end{array}$ & $\begin{array}{c}17.2 \pm 1.3 \\
16.1 \\
9.2 \text { to } 28.7\end{array}$ & $\begin{array}{c}19.1 \pm 2.3 \\
16.2 \\
10.3 \text { to } 31.1\end{array}$ \\
\hline
\end{tabular}


Table 2 IL-10-producing B cells, IDO-expressing dendritic cells and forkhead box protein 3-expressing regulatory T peripheral cells (Continued)

\begin{tabular}{|c|c|c|c|c|c|c|c|c|c|c|}
\hline $\begin{array}{l}\mathrm{CD} 123^{+} / \mathrm{CCR}^{+} \\
\text {Mean } \pm \mathrm{SEM} \\
\text { Median } \\
\text { Range }\end{array}$ & $\begin{array}{l}0.40 \pm 0.06 \\
0.35 \\
0.12 \text { to } 0.98\end{array}$ & $\begin{array}{c}0.35 \pm 0.07 \\
0.2 \\
0.03 \text { to } 2.89\end{array}$ & $\begin{array}{l}0.29 \pm \\
0.06 \\
0.2 \\
0.07 \text { to } \\
0.82\end{array}$ & $\begin{array}{l}0.38 \pm 0.11 \\
0.19 \\
0.03 \text { to } 2.89\end{array}$ & $\begin{array}{c}0.29 \pm 0.34 \\
0.2 \\
0.03 \text { to } 1.84\end{array}$ & $\begin{array}{c}0.42 \pm 0.18 \\
0.2 \\
0.07 \text { to } 2.9\end{array}$ & $\begin{array}{c}0.3 \pm 0.06 \\
0.21 \\
0.08 \text { to } 0.72\end{array}$ & $\begin{array}{l}0.14 \pm 0.03 \\
0.15 \\
0.07 \text { to } 0.2\end{array}$ & $\begin{array}{l}0.29 \pm 0.10 \\
0.15 \\
0.03 \text { to } 1.84\end{array}$ & $\begin{array}{l}0.46 \pm 0.27 \\
0.20 \\
0.13 \text { to } 2.89\end{array}$ \\
\hline $\begin{array}{l}\mathrm{CD}_{+} 123^{+} / \mathrm{CCR}^{+} / \mathrm{IDO} \\
\end{array}$ & $\begin{array}{c}16.6 \pm 1.0 \\
16.7\end{array}$ & $\begin{array}{c}27.4 \pm 1.8 \\
26.7^{\mathrm{e}}\end{array}$ & $\begin{array}{c}30.8 \pm 3.5 \\
28.7^{\mathrm{e}}\end{array}$ & $\begin{array}{c}25.5 \pm 2.0 \\
23.9^{\mathrm{e}}\end{array}$ & $\begin{array}{c}28.0 \pm 2.3 \\
27.7^{\mathrm{e}}\end{array}$ & $\begin{array}{c}28.4 \pm 3.2 \\
28.2^{\mathrm{e}}\end{array}$ & $\begin{array}{c}31.4 \pm 4.5 \\
28.9^{\mathrm{e}}\end{array}$ & $\begin{array}{c}31.9 \pm 6.0 \\
32.8 \text { c e }\end{array}$ & $\begin{array}{c}25.5 \pm 2.4 \\
27.4^{\mathrm{e}}\end{array}$ & $\begin{array}{c}27.2 \pm 3.9 \\
27.1^{\mathrm{e}}\end{array}$ \\
\hline $\begin{array}{l}\text { Mean } \pm \text { SEM } \\
\text { Median } \\
\text { Range }\end{array}$ & 10.2 to 29.6 & 7.4 to 57.2 & $\begin{array}{c}14.2 \text { to } \\
57.2\end{array}$ & 7.4 to 49.4 & 7.4 to 57.2 & 12.1 to 49.4 & 14.2 to 57.2 & 18.0 to 44.0 & 7.4 to 43.0 & 12.1 to 49.4 \\
\hline \multicolumn{11}{|l|}{$\begin{array}{l}\text { Foxp3-expressing T } \\
\text { cells (\%) }\end{array}$} \\
\hline $\begin{array}{l}\mathrm{CD}^{+} \\
\text {Mean } \pm \text { SEM } \\
\text { Median } \\
\text { Range }\end{array}$ & $\begin{array}{l}28.4 \pm 1.3 \\
26.6 \\
18.7 \text { to } 43.0\end{array}$ & $\begin{array}{l}22.7 \pm 1.4 \\
22.7 \\
7.1 \text { to } 45.7\end{array}$ & $\begin{array}{c}20.6 \pm 2.1 \\
17.3 \\
10.8 \text { to } \\
45.7\end{array}$ & $\begin{array}{l}23.5 \pm 1.8 \\
25.2 \\
7.1 \text { to } 39.8\end{array}$ & $\begin{array}{l}22.1 \pm 1.8 \\
21.4 \\
7.1 \text { to } 45.7\end{array}$ & $\begin{array}{l}23.3 \pm 2.5 \\
26.1 \\
8.6 \text { to } 39.8\end{array}$ & $\begin{array}{c}21.1 \pm 2.7 \\
18.2 \\
12.5 \text { to } 45.7\end{array}$ & $\begin{array}{c}18.0 \pm 4.1 \\
15.7 \\
10.8 \text { to } 29.9\end{array}$ & $\begin{array}{l}22.8 \pm 2.4 \\
23.0 \\
7.1 \text { to } 38.0\end{array}$ & $\begin{array}{l}25.4 \pm 3.3 \\
26.9 \\
8.6 \text { to } 39.8\end{array}$ \\
\hline $\begin{array}{l}\mathrm{CD} 4^{+} / \mathrm{CD} 25^{\mathrm{hi}} \\
\text { Mean } \pm \text { SEM } \\
\text { Median } \\
\text { Range }\end{array}$ & $\begin{array}{l}0.78 \pm 0.14 \\
0.54 \\
0.17 \text { to } 2.69\end{array}$ & $\begin{array}{l}0.36 \pm 0.06 \\
0.26^{\mathrm{e}} \\
0.10 \text { to } 2.93\end{array}$ & $\begin{array}{c}0.27 \pm \\
0.04 \\
0.20^{\mathrm{e}} \\
0.12 \text { to } \\
0.64\end{array}$ & $\begin{array}{l}0.40 \pm 0.09 \\
0.27 \\
0.10 \text { to } 2.93\end{array}$ & $\begin{array}{l}0.27 \pm 0.03 \\
0.25^{e} \\
0.10 \text { to } 0.80\end{array}$ & $\begin{array}{l}0.52 \pm 0.17 \\
0.28 \\
0.12 \text { to } 2.93\end{array}$ & $\begin{array}{l}0.28 \pm 0.04 \\
0.23 \\
0.12 \text { to } 0.64\end{array}$ & $\begin{array}{c}0.28 \pm 0.09 \\
0.28 \\
0.12 \text { to } 0.44\end{array}$ & $\begin{array}{l}0.27 \pm 0.04 \\
0.25^{\mathrm{e}} \\
0.10 \text { to } 0.80\end{array}$ & $\begin{array}{c}0.53 \pm 0.24 \\
0.28 \\
0.12 \text { to } 2.93\end{array}$ \\
\hline $\begin{array}{l}\text { CD4 } 4^{+} / \text {CD } 25^{\text {hi}} / \text { Foxp3 } \\
+ \\
\text { Mean } \pm \text { SEM } \\
\text { Median } \\
\text { Range }\end{array}$ & $\begin{array}{l}5.7 \pm 0.3 \\
5.8 \\
3.3 \text { to } 9.0\end{array}$ & $\begin{array}{c}6.4 \pm 0.4 \\
6.5 \\
1.4 \text { to } 11.2\end{array}$ & $\begin{array}{c}6.2 \pm 0.6 \\
5.9 \\
2.2 \text { to } \\
11.2\end{array}$ & $\begin{array}{l}6.5 \pm 0.4 \\
6.6 \\
1.4 \text { to } 10.9\end{array}$ & $\begin{array}{l}6.7 \pm 0.5 \\
\quad 6.9 \\
2.0 \text { to } 11.6\end{array}$ & $\begin{array}{c}6.1 \pm 0.6 \\
6.1 \\
1.4 \text { to } 10.9\end{array}$ & $\begin{array}{c}6.6 \pm 0.8 \\
6.4 \\
2.2 \text { to } 11.2\end{array}$ & $\begin{array}{l}6.2 \pm 1.2 \\
5.8 \\
4.0 \text { to } 9.2\end{array}$ & $\begin{array}{c}6.8 \pm 0.6 \\
6.9 \\
2.0 \text { to } 10.4\end{array}$ & $\begin{array}{c}6.0 \pm 0.7 \\
6.1 \\
1.4 \text { to } 10.9\end{array}$ \\
\hline $\begin{array}{l}\mathrm{CD}^{+} \\
\text {Mean } \pm \text { SEM } \\
\text { Median } \\
\text { Range }\end{array}$ & $\begin{array}{l}10.5 \pm 0.8 \\
10.6 \\
3.5 \text { to } 16.7\end{array}$ & $\begin{array}{c}12.2 \pm 1.2 \\
10.1 \\
3.2 \text { to } 38.4\end{array}$ & $\begin{array}{c}12.6 \pm 2.5 \\
8.7 \\
3.2 \text { to } \\
38.4\end{array}$ & $\begin{array}{l}11.8 \pm 1.3 \\
10.7 \\
3.3 \text { to } 27.0\end{array}$ & $\begin{array}{l}13.0 \pm 1.8 \\
9.7 \\
3.2 \text { to } 38.4\end{array}$ & $\begin{array}{l}10.9 \pm 1.5 \\
10.5 \\
3.3 \text { to } 27.0\end{array}$ & $\begin{array}{c}14.4 \pm 3.5 \\
10.1 \\
3.2 \text { to } 38.4\end{array}$ & $\begin{array}{l}8.2 \pm 1.9 \\
6.6 \\
5.8 \text { to } 13.9\end{array}$ & $\begin{array}{l}12.1 \pm 2.0 \\
9.7 \\
3.5 \text { to } 25.6\end{array}$ & $\begin{array}{c}12.3 \pm 2.1 \\
12.0 \\
3.3 \text { to } 27.0\end{array}$ \\
\hline $\begin{array}{l}\mathrm{CD}^{+} / \mathrm{CD}_{28} 8^{-} \\
\text {Mean } \pm \mathrm{SEM} \\
\text { Median } \\
\text { Range }\end{array}$ & $\begin{array}{l}3.7 \pm 0.3 \\
3.4 \\
1.1 \text { to } 8.2\end{array}$ & $\begin{array}{l}5.1 \pm 0.6 \\
3.6 \\
0.8 \text { to } 17.4\end{array}$ & $\begin{array}{c}5.4 \pm 1.2 \\
3.4 \\
1.0 \text { to } \\
17.4\end{array}$ & $\begin{array}{c}4.9 \pm 0.6 \\
3.7 \\
0.8 \text { to } 13.6\end{array}$ & $\begin{array}{c}5.8 \pm 0.9 \\
4.0 \\
0.8 \text { to } 17.4\end{array}$ & $\begin{array}{c}4.1 \pm 0.6 \\
3.6 \\
1.4 \text { to } 9.3\end{array}$ & $\begin{array}{c}6.1 \pm 1.6 \\
3.7 \\
1.0 \text { to } 17.4\end{array}$ & $\begin{array}{c}4.0 \pm 1.3 \\
3.5 \\
1.4 \text { to } 7.4\end{array}$ & $\begin{array}{c}5.6 \pm 1.0 \\
4.9 \\
0.8 \text { to } 13.6\end{array}$ & $\begin{array}{c}4.1 \pm 0.7 \\
3.6 \\
1.6 \text { to } 9.3\end{array}$ \\
\hline $\begin{array}{l}\text { CD8 } 8^{+} / \mathrm{CD}_{2} 8^{-} / \text {Foxp3 } \\
+ \\
\text { Mean } \pm \mathrm{SEM} \\
\text { Median } \\
\text { Range }\end{array}$ & $\begin{array}{c}5.6 \pm 0.3 \\
5.6 \\
2.8 \text { to } 8.8\end{array}$ & $\begin{array}{c}3.9 \pm 0.3 \\
3.7^{\mathrm{e}} \\
1.1 \text { to } 8.9\end{array}$ & $\begin{array}{c}4.2 \pm 0.6 \\
4.0 \\
1.2 \text { to } 8.9\end{array}$ & $\begin{array}{c}3.8 \pm 0.3 \\
3.6^{\mathrm{e}} \\
1.1 \text { to } 7.3\end{array}$ & $\begin{array}{c}3.9 \pm 0.4 \\
3.5 \text { e } \\
1.1 \text { to } 8.9\end{array}$ & $\begin{array}{c}4.2 \pm 0.5 \\
4.4 \\
1.8 \text { to } 8.5\end{array}$ & $\begin{array}{c}4.0 \pm 0.8 \\
3.7 \\
1.3 \text { to } 8.9\end{array}$ & $\begin{array}{c}5.3 \pm 1.2 \\
5.1 \\
2.6 \text { to } 8.5\end{array}$ & $\begin{array}{c}3.8 \pm 0.5 \\
3.5 \text { e } \\
1.1 \text { to } 7.3\end{array}$ & $\begin{array}{c}3.9 \pm 0.5 \\
3.9^{\mathrm{e}} \\
1.8 \text { to } 6.8\end{array}$ \\
\hline
\end{tabular}

Control, control group of healthy individuals. ${ }^{a} P<0.05$ : patients with clinically active versus clinically inactive primary Sjögren's syndrome (pSS); ${ }^{\text {b } P<0.05: ~ p a t i e n t s ~ w i t h ~ s e r o l o g i c a l l y ~ a c t i v e ~ v e r s u s ~ s e r o l o g i c a l l y ~}$ inactive $\mathrm{pSS} ;{ }^{c} p<0.05$ : patients with clinically and serologically active versus clinically active but serologically inactive $\mathrm{pSS}$; ${ }^{\mathrm{d}} p<0.05$ : patients with clinically inactive but serologically active versus clinically and serologically inactive pSS. IDO, indoleamine 2,3-dioxygenase; PBMCs, peripheral blood mononuclear cells; SEM, standard error of the mean; pDC, plasmacytoid dendritic cells. 


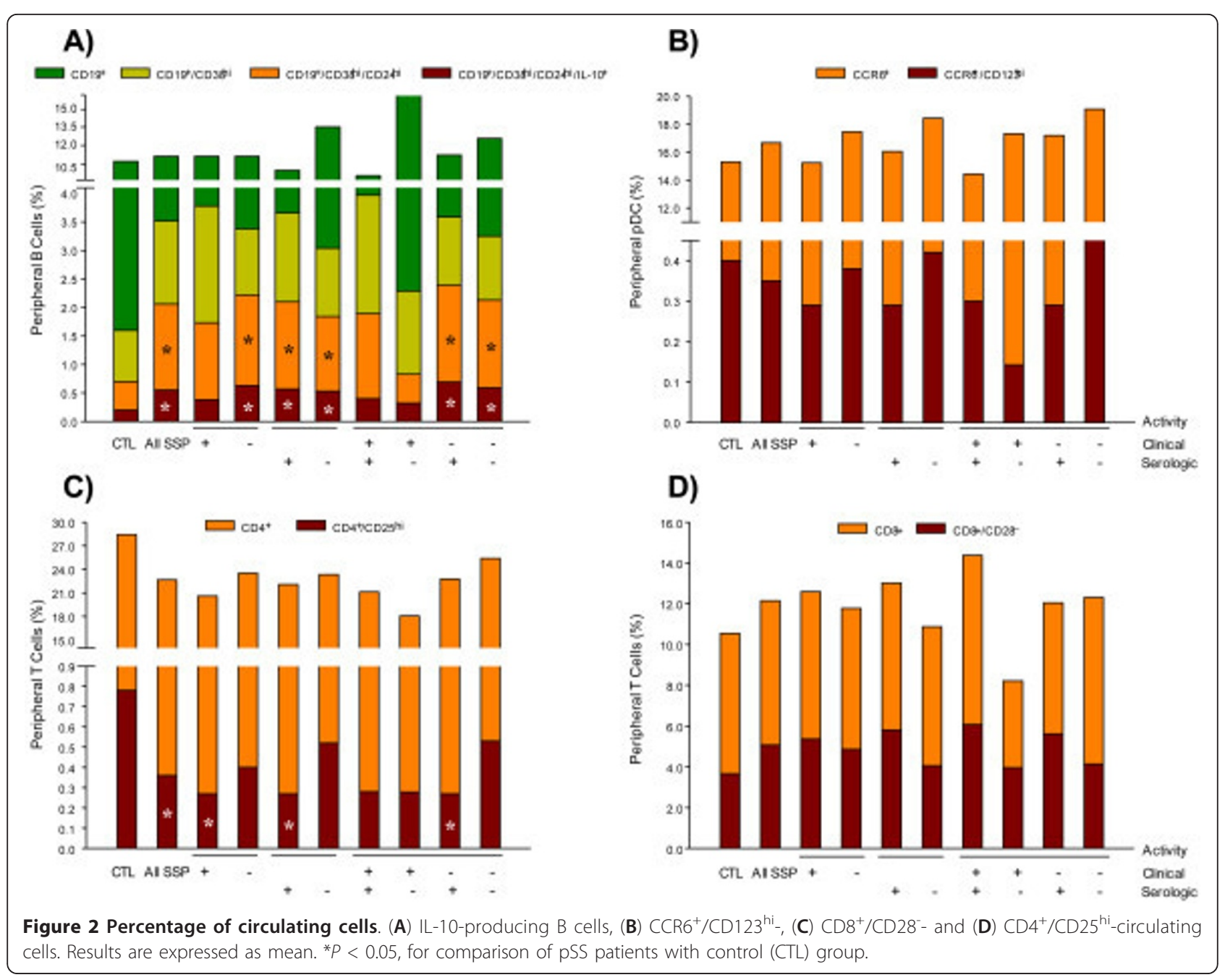

\section{Discussion}

For a long time, pSS was considered a Th1 autoimmune disease, and this lymphocyte subset has been the protagonist of immune damage. Nevertheless, the contemporary view of pSS considers the B cell population as preponderant in its pathogenesis [22]. Nevertheless, this new hypothesis does not consider regulatory B cells, probably due the recent description or the scarce information about their role in pSS. Recently, however, phenotypic and functional features of these novel IL-10-producing $B$ cells have been described, for example, they are potent suppressors of Th1 cell differentiation (through cell-cell contact and production of IL-10), are inhibitors of autoimmune pathogenesis, and importantly, can restore immune system homeostasis [31]. It is worth mentioning that regulatory B cells represent only 0.2 to $0.6 \%$ of total $\mathrm{B}$ cells, suggesting that its regulatory potential is highly effective.

The objective of this study was to characterize three subpopulations of regulatory cells namely, IL-10-producing
B cells, Foxp3-expressing T cells and IDO-expressing DCs in 50 patients with clinically active or inactive and serologically active or inactive pSS. Unexpectedly, $\mathrm{CD} 4^{+} / \mathrm{CD} 25^{\mathrm{hi}}$ / Foxp $^{+}$regulatory $\mathrm{T}$ cells were comparable between all pSS groups, suggesting that, at least systemically, these cells are not affected by clinical or serologic pSS activity and, moreover, do not appear to be an important peripheral cell biomarker. Furthermore, in an indirect way, these data support the hypothesis of the key role B cells play in disease pathogenesis $[22,31,32]$.

Furthermore, a previous study reported that the number of infiltrating $\mathrm{CD} 4^{+} / \mathrm{CD} 25^{\mathrm{hi}} / \mathrm{Foxp}^{+}$cells positively correlated with the minor salivary gland biopsy focus score and negatively correlated with the prevalence of these cells in the peripheral blood, suggesting a reverse regulation in the periphery and the affected tissue. Nevertheless, in patients with advanced histologic lesions, high percentages of Treg cells were detected in peripheral blood [33]. According to our data, we also support the low prevalence of these circulating cells suggesting a 


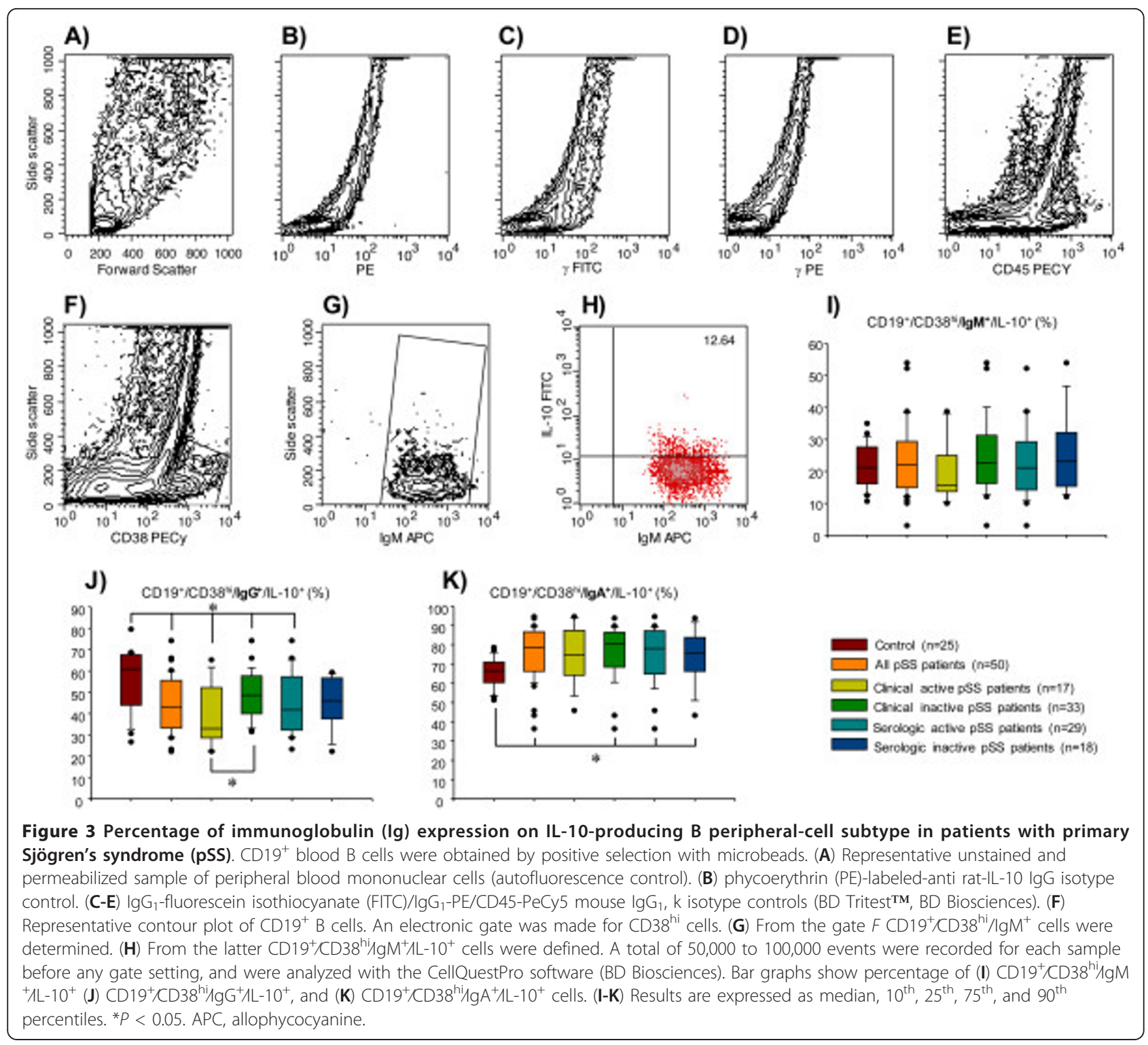

reverse peripheral regulation and injured tissue. On the other hand, our work provides evidence for the presence of another subpopulation of naturally occurring regulatory $\mathrm{T}$ cells, the $\mathrm{CD} 8^{+} / \mathrm{CD} 28^{-} / \mathrm{Foxp}^{+}{ }^{+}$cell subset. They were found at lower levels in all pSS patient groups when compared with the healthy control group, suggesting that IL-10-producing regulatory $\mathrm{CD} 8^{+} \mathrm{T}$ cells might be migrating to the lacrimal and salivary glands, as a result of their regulatory effect, which appeared to be mediated by direct contact with target cells [32]. Foxp3-expressing $\mathrm{CD}^{+} / \mathrm{CD} 28^{-}$Tregs share developmental and phenotypic features $\left(\mathrm{CD} 122^{+} / \mathrm{GITR}^{+} / \mathrm{CTLA}^{+} / \mathrm{CCR}^{+} / \mathrm{CD} 2 \mathrm{~L}^{+} /\right.$ $\left.\mathrm{CD} 25^{+} / \mathrm{CD} 127^{-} / \mathrm{IL}^{+} 23 \mathrm{R}^{-}\right)$with naturally occurring $\mathrm{CD} 4^{+}$ Tregs. Secretion of IL-10 and transforming growth factor (TGF)- $\beta 1$ is higher in $\mathrm{CD} 8^{+} / \mathrm{CD} 25^{\mathrm{hi}} / \mathrm{CD} 28^{-} /$Foxp3 Tregs than in $\mathrm{CD}^{+} / \mathrm{CD} 25^{\mathrm{hi}} / \mathrm{CD} 28^{-} \mathrm{T}$ cells. In addition, Foxp3expressing $\mathrm{CD}^{+}$Tregs reduce $\mathrm{T}$ cell proliferation in response to a specific antigen and secretion of both IFN$\gamma$ and IL-17 by CD4 T cells only through cell-cell contact. On the other hand, $\mathrm{CD}^{+}$Tregs downregulate the co-stimulatory molecule expression on DCs (CD40, CD80, CD86, MHC I, HLA-DR), inducing a less efficient antigen presentation $[32,34,35]$. It has previously been demonstrated that $\mathrm{CD}^{+} / \mathrm{CD} 28^{-} / \mathrm{Foxp}^{+}{ }^{+}$regulatory $\mathrm{T}$ cells can condition DCs to express functional and suppressive IDO activity [32]. In turn, IDO-expressing pDCs have the capacity to suppress T-cell responses to allo- and autoantigens [36]. In this study, an increase in the percentage of $\mathrm{CD} 123^{\mathrm{hi}} / \mathrm{CCR}^{+} / \mathrm{IDO}^{+}$pDC was observed in all pSS patient groups when compared with the peripheral 


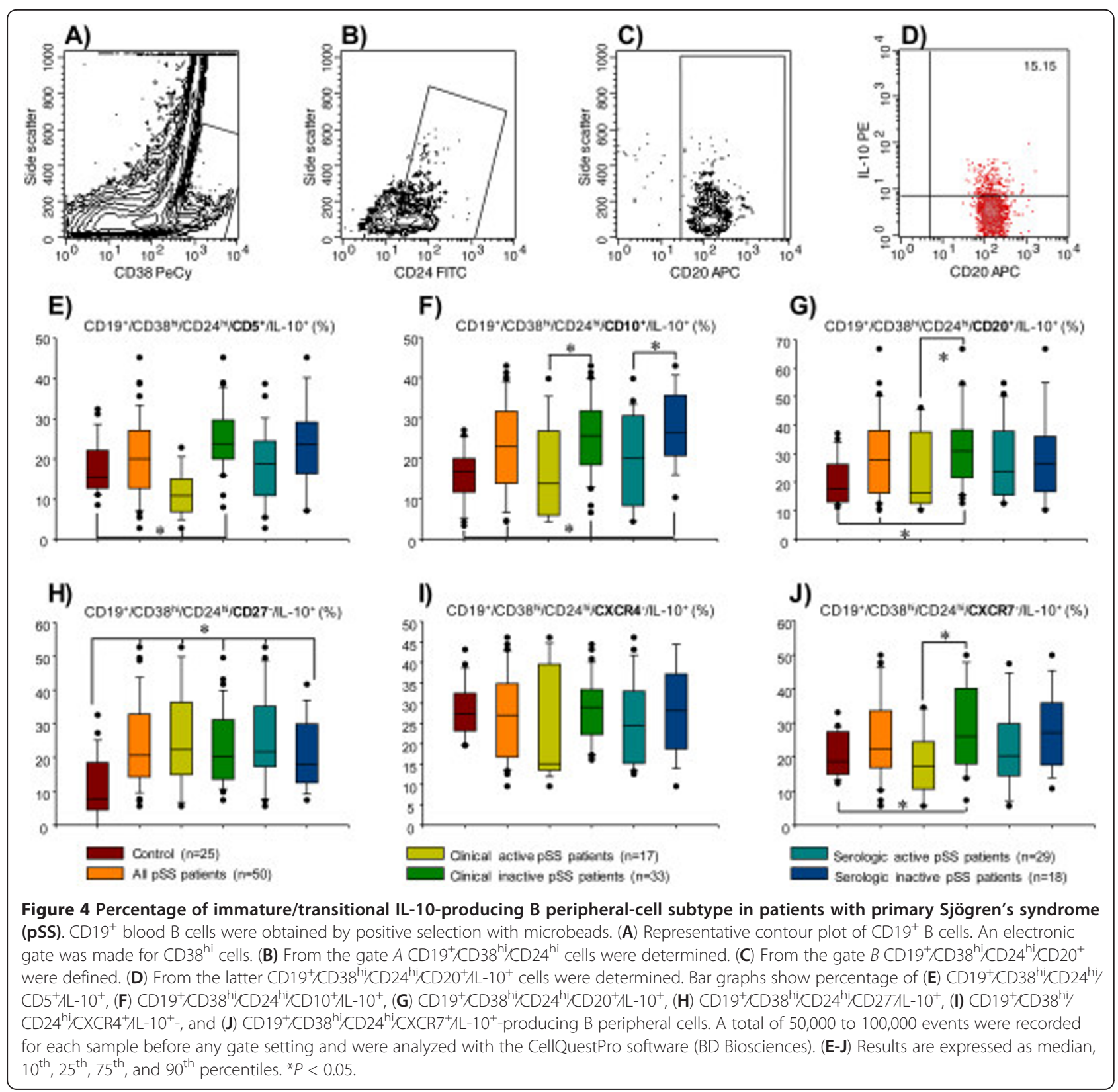

frequency observed in healthy subjects. The role of IDO and the specific IDO-expressing cells in normal and disease conditions has not yet been fully characterized. $\mathrm{CD} 123^{\mathrm{hi}} / \mathrm{CCR}^{+} / \mathrm{IDO}^{+}$pDC constitute only 0.2 to $0.8 \%$ of peripheral blood cells and represent a unique, rather plastic, versatile, and important immune cell population capable of producing over $95 \%$ of IFN-I synthesized by $\mathrm{PBMC}$ in response to virus and nucleic acid-containing complexes from the host [37]. In fact, IFN-I upregulation has been shown in both peripheral cells and salivary glands from pSS patients, the so-called IFN signature [38], and it has been postulated that a primary viral infection induces IFN-I synthesis in salivary glands with subsequent activation of the adaptive immune response resulting in autoantibody production against RNA binding proteins, for example, SSA, SSB, RNP, which are interferogenic complexes that stimulate CD123 $3^{\mathrm{hi}} / \mathrm{CCR}^{+}$/ IDO $^{+}$cells to synthesize IFN-I, although this does not distinguish clinical disease activity. Thus, DCs could play a dual role in pSS pathogenesis: regulation of the immune response and IFN-I production.

In addition to several Tregs and DCregs, our results show that human peripheral blood has at least one more tolerogenic subset, namely IL-10-secreting B cells. Mauri and colleagues have defined these latter cells as a regulatory B-cell pool with many subtypes that display a 


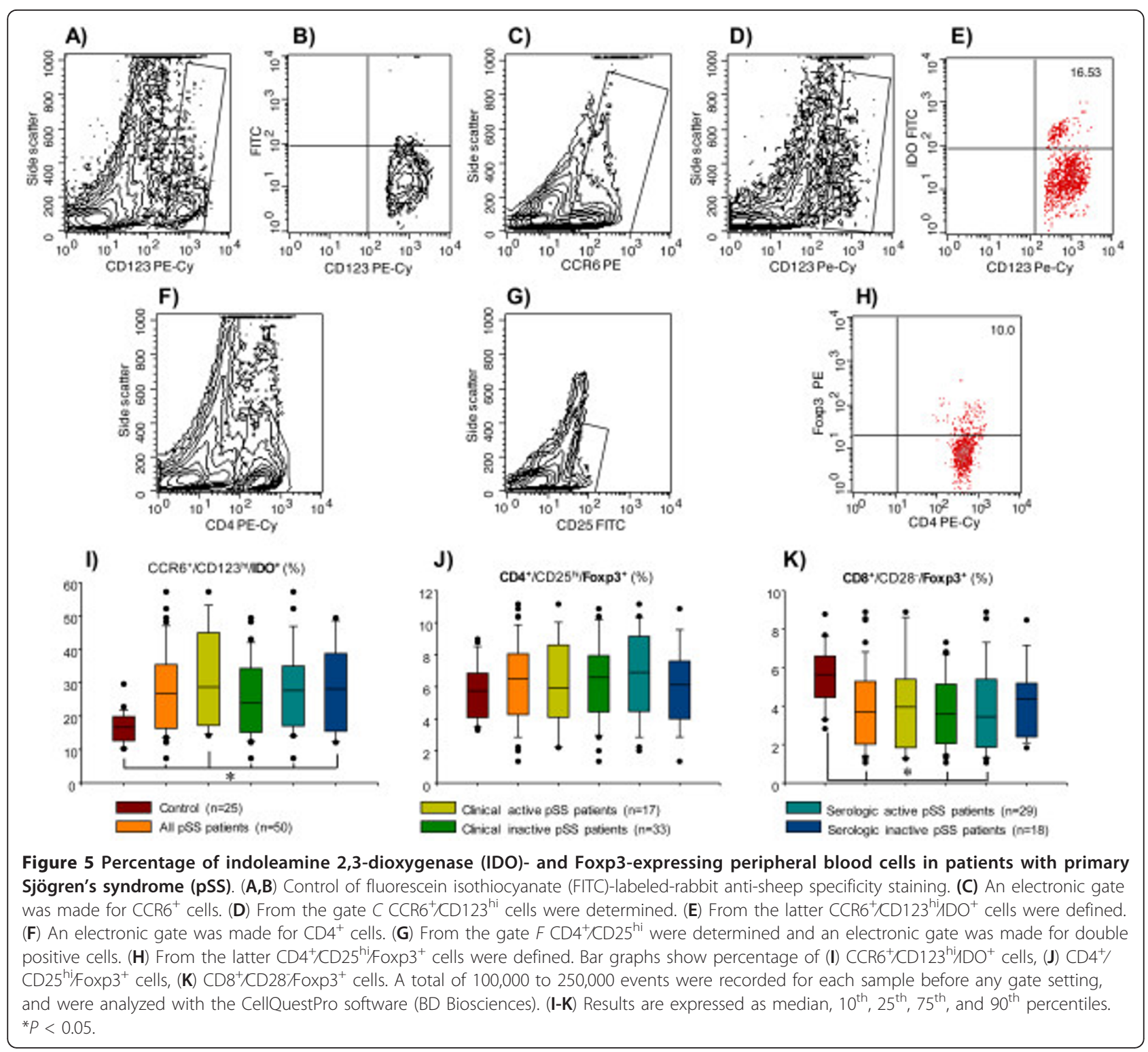

CD $19^{+} / \mathrm{CD} 24^{\mathrm{hi}} / \mathrm{CD} 38^{\mathrm{hi}} / \mathrm{IL}-10^{+}$phenotype [31]. Iwatta et al. previously reported that $\mathrm{CD} 19^{+} / \mathrm{CD} 24^{\mathrm{hi}} / \mathrm{CD} 38^{\mathrm{hi}} /$ $\mathrm{CD} 27^{+} / \mathrm{IL}-10^{+}$B10-cell frequencies in blood from a group of patients with autoimmune diseases, such as lupus, rheumatoid arthritis, SS, autoimmune skin disease, and multiple sclerosis, were not significantly different from those observed in healthy controls, although mean B10 and B10 pro-cell frequencies were significantly increased. However no further characterization for each disease was provided [39].

Herein, the regulatory B-cell subset percentage showed clear differences in pSS patients with active versus inactive disease. $\mathrm{CD} 19^{+} / \mathrm{CD} 24^{\mathrm{hi}} / \mathrm{CD} 38^{\mathrm{hi}} / \mathrm{IL}-10^{+}$cells were significantly higher in the whole pSS group compared to HD. However, this difference was at the expense of pSS patients with clinically inactive disease, where IgAexpressing regulatory B cells have higher peripheral frequency. IgA secretion by the salivary gland in pSS patients suggests that its peripheral blood occurrence is a clear systemic reflection of what might be happening at the site of injury. Our suggestion is based on work by Cerutti's group who have clearly shown that functional toll-like receptor (TLR)3 is expressed by human tonsillar B-cells, with higher expression in GCs and sub-epithelial regions, but is absent from memory B cells $\left(\mathrm{CD} 27^{+}\right.$cells). In the presence of dsRNA, these mucosal B cells upregulate AID expression and initiate class switch recombination and IgG/IgA production in the presence of IL-10 and B cell activating factor (BAFF) [40]. Surprisingly, IgG-expressing regulatory B cells had lower peripheral 
frequency in patients compared to healthy individuals. The lowest frequency was found in pSS patients with clinically active versus inactive disease. There was no difference between patients and controls in surface IgM expression.

Recently, a CD $19^{+} / \mathrm{CD} 24^{\mathrm{hi}} / \mathrm{CD} 38^{\mathrm{hi}} / \mathrm{CD} 5^{\mathrm{hi}}$ B-cell subtype has been described. CD5 itself has been demonstrated to affect $\mathrm{B}$-cell function by negative regulation of $\mathrm{B}$-cell receptor (BCR) signaling, as well as by inducing the production of IL-10 [41]. $\mathrm{CD}^{+}$IL-10-producing B cells suppress the proliferation of Th1 through CD40 engagement, and STAT3 phosphorylation. Meanwhile, the differentiation of Th1 cells is inhibited in an IL-10dependent, but TGF- $\beta 1$-independent manner, which requires $\mathrm{CD} 80 / \mathrm{CD} 86$ interactions with target $\mathrm{CD} 4^{+}$ T-cells. In addition to halting Th1 but not Th17 responses, the suppressive effects are mediated by an indirect mechanism, through the induction of Foxp $3^{+}$ expression in $\mathrm{CD} 4^{+} / \mathrm{CD} 25^{\text {hi }} \mathrm{T}$ cells $[4,9]$ in a more efficient way than any other population of antigen-presenting cells $[5,6]$. The resulting Tregs displayed a greater suppressive capacity than regulatory $\mathrm{T}$-cells generated by immature DCs from the same donor [7]. This suggests that B celldependent suppressive effects are associated with the generation of Foxp3-expressing CD $4^{+} / \mathrm{CD} 25^{\text {hi }}$ Tregs. In our study we found higher proportions of $\mathrm{CD} 19^{+} / \mathrm{CD} 24^{\mathrm{hi}} /$ CD38 ${ }^{\text {hi }} / \mathrm{CD}^{+}$IL-10-secreting B cells in pSS patients with clinically inactive disease compared to those with clinically active disease, the whole pSS group, and healthy controls, suggesting that $\mathrm{CD} 5^{+} \mathrm{IL}-10$-producing $\mathrm{B}$ cells are able to downregulate autoimmune inflammation to induce homeostasis [5-8].

Another B cell subpopulation in our patients was that of $\mathrm{CD} 19^{+} / \mathrm{CD} 38^{\mathrm{hi}} / \mathrm{CD} 24^{\mathrm{hi}} / \mathrm{CD} 10^{+} / \mathrm{IL}-10^{+}$cells. $\mathrm{CD} 10$ is a cell membrane metallopeptidase expressed by early $\mathrm{B}$, pro-B, and pre-B lymphocytes and diffuse large B cells. $\mathrm{CD} 10$ expression is a well-accepted marker for most of the transitional T1/T2 B-cell pool, suggesting that these cells are recent emigrants from the bone marrow [4]. Our findings show a statistically significant increase in the frequency of these B cells in pSS patients with clinically inactive, serologically inactive, and clinically and serologically inactive disease compared to pSS patients with clinically active, serologically active, and clinically and serologically active disease, and healthy controls, attributable to a more immature differentiation stage of these cells (probably T2) [42].

The levels of the $\mathrm{CD} 19^{+} / \mathrm{CD} 38^{\mathrm{hi}} / \mathrm{CD} 24^{\mathrm{hi}} / \mathrm{CD} 20^{+} / \mathrm{IL}-10^{+}$ $\mathrm{B}$-cell subset were higher in the whole pSS group, and in patients with clinically inactive, and clinically and serologically inactive disease compared to healthy controls. Moreover, levels of $\mathrm{CD} 20^{+} / \mathrm{IL}-10^{+} \mathrm{B}$ cells were significantly lower in pSS patients with clinically active versus clinically inactive disease. CD20 is a 33-kd phosphoprotein similar to an ion channel that allows calcium influx for cell activation. It is expressed on pre-B and mature B cells after CD19/CD10 expression, and before CD21/CD22 and surface Ig expression. It is retained on mature B cells until plasma cell development (plasmablasts) [5]. It has a central role in the generation of T cell-independent (TI) antibody responses. Although antigen-independent $\mathrm{B}$ cells have been shown to develop normally, in the absence of CD20 expression, antibody formation, particularly after vaccination with TI antigens, is strongly impaired in deficient patients [43]. In this sense, we suggest that the decrease in CD20 expression in patients with active pSS could be an immune regulatory mechanism that is able to avoid autoimmune antibody response and maintain the IL-10producing $\mathrm{B}$ cell tolerant phenotype.

In addition to the human $\mathrm{CD} 19^{+} / \mathrm{CD} 24^{\mathrm{hi}} / \mathrm{CD} 38^{\mathrm{hi}}$-circulating B-cell subpopulation aforementioned, it has been suggested that $\mathrm{CD} 19^{+} / \mathrm{CD} 38^{\mathrm{hi}} / \mathrm{CD} 24^{\mathrm{hi}} / \mathrm{CD} 27^{+} / \mathrm{IL}-$ $10^{+}$or B10 cells might be a different Breg subset, as described by Tedder and colleagues [39]. They are present in the splenic marginal zone rather than memory cells generated in germinal centers. Whereas CD40/ CpG-stimulated B10 cells induce proliferation and produce higher levels of IL-10 (10-fold) compared to CD27 (cells that had not yet entered the germinal center), only B10 cells inhibit mitogen-induced TNF- $\alpha$ production by monocytes, through IL-10 synthesis [39,44-48], suggesting neither a non-inflammatory nor a viral infectious process.

Remarkably, when compared to healthy controls, there were higher levels of naïve and transitional $\mathrm{CD} 19^{+} /$ $\mathrm{CD} 38^{\mathrm{hi}} / \mathrm{CD} 24^{\mathrm{hi}} / \mathrm{CD} 27^{-} / \mathrm{IL}-10^{+} \mathrm{B}$ cells in all pSS patient groups except for the group with clinically active and serologically inactive disease. We consider that the relative increase in $\mathrm{CD} 27^{-}$peripheral $\mathrm{B}$ cells could be originated by a B-cell exhaustion mechanism, where accumulation of peripheral blood CD27- tissue-like B cells is a consequence of persistent chronic immune activation (autoimmune disease) or persistent viral infections. The features of $\mathrm{CD}^{2} 7^{-}$ $B$ cells include increased expression of multiple inhibitory receptors, decreased cell function, and poor proliferative and effector responses to a variety of stimuli [49].

Among all chemokine receptors, CXCR4 induces prolonged activation of intracellular signal transduction pathways, such as the mitogen-activated protein kinase (MAPK) cascade. This may elicit anti-apoptotic responses and thus, contribute to cell survival. In B-cell lymphopoiesis, CXCR4/CXCL12 are critical for bone marrow retention and maturation of the cells [50]. In the present study, there were no differences between $\mathrm{CD} 19^{+} / \mathrm{CD} 38^{\mathrm{hi}} /$ $\mathrm{CD} 24^{\mathrm{hi}} / \mathrm{CXCR} 4^{+} / \mathrm{IL}-10^{+}$levels in pSS patients and controls, suggesting that, at least at systemic level, these cells are not affected by clinical or serologic pSS activity: $\mathrm{CD} 19^{+} / \mathrm{CD} 38^{\mathrm{hi}} / \mathrm{CD} 24^{\mathrm{hi}} / \mathrm{CXCR} 7^{+} / \mathrm{IL}-10^{+}$regulatory B cells 
were increased in pSS patients with clinically inactive disease compared to patients with clinically active disease and healthy controls. CXCR7 is a receptor for chemokines CXCL12/SDF1 and CXCL11. It does not elicit classical chemokine receptor signaling; chemokine binding does not activate G-protein-mediated signal transduction, but instead induces beta-arrestin recruitment, leading to ligand internalization and activation of the MAPK signaling pathway. The CXCR7 receptor acts as a scavenger for CXCL12/SDF1 and, to a lesser extent, for CXCL11. It is required for regulation of CXCR4 protein levels in migrating interneurons, thereby adapting their chemokine responsiveness. CXCR7 promotes cell growth and survival. It is not involved in cell migration, adhesion or proliferation of normal hematopoietic progenitors [51,52]. Thus, we suggest that CXCR7 promotes survival of IL-10-producing B cells, and CXCR4 could participate in migrating cells to the site of inflammation, and may perhaps interact in situ with pro-inflammatory cells.

Clinical disease activity necessarily implies the presence of an exacerbation trigger (still unknown) that might overcome the regulatory $\mathrm{B}$ effect by the increase of pathogenic B cells with a concomitant decrease of regulatory B cells. This certainly leads to an uncontrolled autoimmune process and loss of homeostasis. B-cell modulation is clearly a promising therapy in SS. For instance, rituximab (antiCD20 monoclonal antibody) has been employed for the treatment of extraglandular manifestations, features of SS, and fatigue in pSS with controversial results in controlled clinical trials [53]. It eliminates almost all peripheral B cells, again supporting the notion that B cells are the preponderant cells at play in pSS pathogenesis. In the same vein, BAFF is a cytokine clearly implicated in the pathogenesis of SS. Recently, results of a first open, phase 2 study of belimumab, a monoclonal anti-BAFF antibody, showed an improvement in clinical activity assessed by the ESSDAI and ESSPRI indexes [54]. Caution should be taken, because in theory both drugs may also affect the Breg cells and could exacerbate inflammation and autoimmunity.

There are potential limitations to the current study. First, as expected, the group with clinically active disease received steroids and immunosuppressors more frequently (although overall, the latter were not statistically significant when compared to the group with clinically inactive disease); whether or not the impact of the treatment influences the function of regulatory cells is matter of debate. However, we consider that our results are still valid and robust because in the same vein, rheumatoid arthritis patients with inactive disease have also been recently reported as having an increased number of $\mathrm{CD} 19^{+}$ $\mathrm{CD} 24^{\text {hi }} \mathrm{CD} 38^{\mathrm{hi}} \mathrm{B}$ cells compared with patients with active disease [55]. Second, this work was a cross-sectional study.
Thus, longitudinal studies may be necessary for a better understanding of causality.

Nevertheless, as far as we know, this is the first study that evaluated the presence of three regulatory cell subpopulations, particularly, IL-10-producing B cells in pSS patients. Undoubtedly, the immunobiology of regulatory $B$ cells is still young and much remains to be learned about regulatory mechanisms. Next, evaluation should consider exploring ontogeny and population diversity, differentiation pathways, transcription factor(s), specific surface markers, plasticity and functionality of the cells involved. Our preliminary results deserve to be studied in depth to appraise the clinical relevance of these findings. In this vein, the evaluation of these cells in salivary glands is ongoing, to confirm peripheral blood findings, and certainly functional studies will be needed.

\section{Conclusion}

In general it can be concluded that the levels of regulatory B-cell phenotypes studied were greater in patients with clinically inactive pSS and serologically inactive pSS. These findings emphasize two important Breg functions: the control of autoimmune disease and restoration of immune homeostasis. Moreover, Breg immunophenotyping appears to be a reliable marker of cell stability and control of the disease, which may be useful for monitoring those patients who progress to lymphoma.

\section{Abbreviations}

APCs: antigen-presenting cells; APC: allophycocyanine; BAFF: B cell activating factor; BCR: B cell receptor; CpG: cytosine-phopsphate-guanosine; DC: dendritic cell; DCregs: indoleamine 2,3-dioxygenase-expressing dendritic cells; ESSDAl: European League Against Rheumatism Sjögren's syndrome disease activity index; ESR: erythrocyte sedimentation rate; EULAR: European League Against Rheumatism; FACS: fluorescence-activated cell sorting; FITC: fluorescein isothiocyanate; GITR: glucocorticoid-induced tumor necrosis factor receptor; HD: healthy donors; HLA-DR: human leukocyte antigen-DR; IDO: indoleamine 2,3-dioxygenase; IFN- $\gamma$ : interferon- $\gamma$; Ig: immunoglobulin; IL: interleukin; iNKT: inducible natural killer T cells; MAPK: mitogen-activated protein kinase; $\mathrm{MHC}$ I: major histocompatibility complex I; NK: natural killer; PBMC: peripheral blood mononuclear cells; PE: phycoerythrin; PE Cy5: phycoerythrin and Cyanine 5; pDCs: plasmacytoid dendritic cells; pSS: primary Sjögren's syndrome; RNP: ribonucleoprotein; SEM: standard error of the mean; SLE: systemic lupus erythematosus; SSA: Ro/SSA antigen; SSB: La/ SSB antigen; SSDAl: Sjögren's syndrome disease activity index; STAT3: signal transducer and activator of transcription 3; TGF- $\beta 1$ : transforming growth factor $\beta 1$; Th: T helper; TLR: toll-like receptor; TNF-a: tumor necrosis factor-a; Tr1: IL-10-producing Treg cells; Tregs: regulatory Foxp3-expressing T cells.

\section{Competing interests}

The authors declare that they have no competing interests.

\section{Authors' contributions}

JFC, GL, GHM, and LL conceived and designed the experiments. JFC, GL, YRV, and KFB performed the experiments. JFC, GL, and GHM analyzed the data. JFC, GHM, GL, YRV, and LL contributed reagents/materials/analysis tools. JFC, GL, GHM, and LL wrote the paper. All authors read and approved the final manuscript. 


\section{Acknowledgments}

This work was supported by CONACYT and the Miguel Alemán Foundation, Mexico.

Received: 12 November 2012 Revised: 14 January 2013

Accepted: 21 June 2013 Published: 21 June 2013

\section{References}

1. Steinman RM, Nussenzweig MC: Avoiding horror autotoxicus: the importance of dendritic cells in peripheral T cell tolerance. Proc Natl Acad Sci USA 2002, 99:351-358.

2. Wolf $S D$, Dittel BN, Hardardottir F, Janeway CA Jr: Experimental autoimmune encephalomyelitis induction in genetically B cell-deficient mice. J Exp Med 1996, 184:2271-2278.

3. Mizoguchi E, Mizoguchi A, Preffer Fl, Bhan AK: Regulatory role of mature B cells in a murine model of inflammatory bowel disease. Int Immunol 2000, 12:597-605.

4. Blair PA, Noreña LY, Flores-Borja F, Rawlings DJ, Isenberg DA, Ehrenstein MR, Mauri C: $C D 19^{+} C D 24^{\text {hi }} C D 38^{\text {hi }} B$ cells exhibit regulatory capacity in healthy individuals but are functionally impaired in systemic lupus erythematosus patients. Immunity 2010, 32:129-140.

5. Newell KA, Asare A, Kirk AD, Gisler TD, Bourcier K, Suthanthiran M, Burlingham WJ, Marks WH, Sanz I, Lechler RI, Hernandez-Fuentes MP, Turka LA, Seyfert-Margolis VL: Identification of a B cell signature associated with renal transplant tolerance in humans. J Clin Invest 2010, 120:1836-1847.

6. Sagoo P, Perucha E, Sawitzki B, Tomiuk S, Stephens DA, Miqueu P, Chapman S, Craciun L, Sergeant R, Brouard S, Rovis F, Jimenez E, Ballow A, Giral M, Rebollo-Mesa I, Le Moine A, Braudeau C, Hilton R, Gerstmayer B, Bourcier K, Sharif A, Krajewska M, Lord GM, Roberts I, Goldman M, Wood KJ Newell K, Seyfert-Margolis V, Warrens AN, Janssen U, et al: Development of a cross-platform biomarker signature to detect renal transplant tolerance in humans. J Clin Invest 2010, 120:848-861.

7. Pallier A, Hillion S, Danger R, Giral M, Racapé M, Degauque N, Dugast E, Ashton-Chess J, Pettré S, Lozano JJ, Bataille R, Devys A, Cesbron-Gautier A, Braudeau C, Larrose C, Soulillou JP, Brouard S: Patients with drug-free long-term graft function display increased numbers of peripheral $B$ cells with a memory and inhibitory phenotype. Kidney Int 2010, 78:503-513.

8. Le Texier L, Thebault P, Lavault A, Usal C, Merieau E, Quillard T, Charreau B, Soulillou JP, Cuturi MC, Brouard S, Chiffoleau E: Long-term allograft tolerance is characterized by the accumulation of $B$ cells exhibiting an inhibited profile. Am J Transplant 2011, 11:429-438.

9. Lemoine S, Morva A, Youinou P, Jamin C: Human T cells induce their own regulation through activation of B cells. J Autoimmun 2011, 36:228-238.

10. Munn DH, Sharma MD, Mellor AL: Ligation of B7-1/B7-2 by human CD4+ $T$ cells triggers indoleamine 2,3-Dioxygenase activity in dendritic cells. J Immunol 2004, 172:4100-4110.

11. Mellor AL, Keskin DB, Johnson T, Chandler P, Munn DH: Cells expressing indoleamine 2,3-dioxygenase inhibits T cell responses. J Immunol 2002, 168:3771-3776.

12. Fallarino F, Vacca C, Orabona C, Belladonna ML, Bianchi R, Marshall B, Keskin DB, Mellor AL, Fioretti MC, Grohmann U, Puccetti P: Functional expression of indoleamine 2,3-dioxygenase by murine CD8a+ dendritic cells. Int Immunol 2002, 14:65-68.

13. Zhu L, Ji F, Wang Y, Zhang Y, Liu Q, Zhang JZ, Matsushima K, Cao Q, Zhang $Y$ : Synovial autoreactive $T$ cells in rheumatoid arthritis resist IDOmediated inhibition. J Immunol 2006, 177:8226-8233.

14. Mellor AL, Munn DH: Tryptophan catabolism and T-cell tolerance: immunosuppression by starvation? Immunology Today 1999, 20:469-473.

15. Mellor AL, Keskin DB, Johnson T, Chandler P, Munn DH: Cells expressing indoleamine 2,3-dioxygenase inhibits T cell responses. J Immunol 2002, 168:3771-3776.

16. Mellor AL, Munn DH: Tryptophan catabolism and regulation of adaptive immunity. J Immunol 2003, 170:5809-5813.

17. Mellor AL, Munn DH: IDO expression by dendritic cells: tolerance and tryptophan catabolism. Nature Rev Immunol 2004, 4:762-774.

18. Kavousnaki M, Makrigiannakis A, Boumpas D, Verginis P: Novel role of plasmacytoid dendritic cells in humans. Induction of interleukin-10producing Treg cells by plasmacytoid dendritic cells in patients with rheumatoid arthritis responding to therapy. Arthritis Rheum 2010, 62:53-63.
19. Grohmann U, Volpi C, Fallarino F, Bozza S, Bianchi R, Vacca C, Orabona C, Belladonna ML, Ayroldi E, Nocentini G, Boon L, Bistoni F, Fioretti MC, Romani L, Riccardi C, Puccetti P: Reverse signaling through GITR ligand enables dexamethasone to active IDO in allergy. Nat Med 2007, 13:579-586.

20. Puccetti P, Fallarino F: Generation of T cell regulatory activity by plasmacytoid dendritic cells and tryptophan catabolism. Blood cells $\mathrm{Mol}$ Dis 2008, 40:101-105.

21. Szodoray P, Papp G, Horvath IF, Barath S, Sipka S, Nakken B, Zeher M: Cell with regulatory function of the innate and adaptive immune system in primary Sjögren's syndrome. Clin Exp Immunol 2009, 157:343-349.

22. Youinou P, Saraux A, Pers JO: B-Lymphocytes govern the pathogenesis of Sjögren's Syndrome. Curr Pharm Biotechnol 2012, 13:2071-2077.

23. Bohnhorst Jø, Bjørgan MB, Thoen JE, Natvig JB, Thompson KM: Bm1-Bm5 classification of peripheral blood $B$ cells reveals circulating germinal center founder cells in healthy individuals and disturbance in the B cell subpopulations in patients with primary Sjögren's Syndrome. J Immunol 2001, 167:3610-3618

24. Binard A, Le Pottier L, Devauch Sjelle-Pensec V, Saraux A, Youinou P, Pers J-O: Is the blood B-cell subset profile diagnostic for Sjögren syndrome? Ann Rheum Dis 2009, 68:1447-1452.

25. Hernández-Molina G, Leal-Alegre G, Michel-Peregrina M: The meaning of anti-Ro and anti-La antibodies in primary Sjögren's syndrome. Autoimmunity Rev 2011, 10:123-125.

26. Furuzawa-Carballeda J, Lima G, Simancas $P$, Ramos-Bello R, Simancas $M$, Bostock IC, Vilatobá M, Gabilondo B, Granados J, Morales-Buenrostro L, Alberú J, Llorente L: Peripheral regulatory cells immunophenotyping in kidney transplant recipients with different clinical profiles: a crosssectional study. J Transplant 2012, 2012:256960.

27. Lee J, Kuchen S, Fischer R, Chang S, Lipsky PE: Identification and characterization of a human $\mathrm{CD} 5(+)$ pre-naive $B$ cell population. J Immunol 2009, 182:4116-4126.

28. Vitali C, Bombardieri S, Jonsson R, Moutsopoulos HM, Alexander EL, Carsons SE, Daniels TE, Fox PC, Fox Rl, Kassan SS, Pillemer SR, Talal N, Weisman MH: Classification criteria for Sjögren's Syndrome: a revised version of the European criteria proposed by the American-European Consensus Group. Ann Rheum Dis 2002, 61:554-558.

29. Seror R, Ravaud P, Bowman SJ, Baron G, Tzioufas A, Theander E, Gottenberg JE, Bootsma H, Mariette X, Vitali C: EULAR Sjögren's syndrome disease activity index (ESSDAI): development of a consensus systemic disease activity for primary Sjögren's syndrome. Ann Rheum Dis 2010, 69:1103-1109.

30. Vitali C, Palombi G, Baldini C, Benucci M, Bombardieri S, Covelli M, Del Papa N, De Vita S, Epis O, Franceschini F, Gerli R, Govoni M, Bongi SM, Maglione W, Migliaresi S, Montecucco C, Orefice M, Priori R, Tavoni A, Valesini G: Sjögren's syndrome disease damage index and disease activity index. Arthritis Rheum 2007, 56:2223-2231.

31. Mauri C, Blair P: Regulatory B cells in autoimmunity: development and controversies. Nat Rev Rheumatol 2010, 6:636-643.

32. Correale J, Villa A: Role of CD8+CD25+Foxp3+ regulatory T cells in multiple sclerosis. Ann Neurol 2010, 67:625-638.

33. Christodoulou M, Kapsogeorgou E, Motusopoulos N, Moutsopoulos H: Foxp3+ T-regulatory cells in Sjögren's syndrome: correlation with the grade of the autoimmune lesion and certain adverse prognostic factors. Am J Pathol 2008, 173:1389-1396.

34. Yang ZQ, Yang ZY, Zhang LD, Wang SG, Ma KS, Li XW, Dong JH: Increased liver-infiltrating $\mathrm{CD}^{+} \mathrm{FoxP}^{+}$regulatory $\mathrm{T}$ cells are associated with tumour stage in hepatocellular carcinoma patients. Hum Immunol 2010, 71:1180-1186.

35. Peterson RA: Regulatory T-cells: Diverse phenotypes integral to immune homeostasis and suppression. Toxicol Pathol 2012, 40:186-204.

36. Munn DH, Sharma MD, Lee JR, Jhaver KG, Johnson TS, Keskin DB, Marshall B, Chandler P, Antonia SJ, Burgess R, Slingluff CL Jr, Mellor AL: Potential regulatory function of human dendritic cells expressing indoleamine 2,3-dioxygenase. Science 2002, 297:1867-1870.

37. Manlapat AK, Kahler DJ, Chandler PR, Munn DH, Mellor AL: Cellautonomous control of interferon type I expression by indoleamine 2,3dioxygenase in regulatory CD19+ dendritic cells. Eur J Immunol 2007, 37:1064-1071.

38. Gottenberg JE, Cagnard N, Lucchesi C, Letourneur F, Mistou S, Lazure T, Jacques S, Ba N, Ittah M, Lepajolec C, Labetoulle M, Ardizzone M, Sibilia J, 
Fournier C, Chiocchia G, Mariette X: Activation of IFN pathways and plasmacytoid dendritic cell recruitment in target organs of primary Sjögren syndrome. Proc Nat Acad Sci USA 2006, 103:2770-2775.

39. Iwata Y, Matsushita T, Horikawa M, Dilillo DJ, Yanaba K, Venturi GM, Szabolcs PM, Bernstein SH, Magro CM, Williams AD, Hall RP, St Clair EW Tedder TF: Characterization of a rare IL-10-competent B-cell subset in humans that parallels mouse regulatory B10 cells. Blood 2011, 117:530-541.

40. Xu W, Santini PA, Matthews AJ, Chiu A, Plebani A, He B, Chen K, Cerutti A: Viral double-stranded RNA triggers Ig class switching by activating upper respiratory mucosa $B$ cells through an innate TLR3 pathway involving BAFF. J Immunol 2008, 181:276-287.

41. Garau S, Le Dantec C, de Mendoza AR, Mageed RA, Youinou P, Renaudineau Y: IL-10 production by B cells expressing CD5 with the alternative exon 1B. Ann NY Acad Sci 2009, 1173:280-285.

42. Bouaziz JD, Calbo S, Maho-Vaillant M, Saussine S, Bagot M, Bensussan A, Musette P: IL-10 produced by activated human B cells regulates CD4(+) T-cell activation in vitro. Eur J Immunol 2010, 40:2686-2691.

43. Kuijpers TW, Bende RJ, Baars PA, Grummels A, Derks IAM, Dolman KM, Beaumont T, Tedder TF, van Noesel CJM, Eldering E, van Lier RAW: CD20 deficiency in humans results in impaired T cell-independent antibody responses. J Clin Invest 2010, 120:214-222.

44. Weill JC, Weller S, Reynaud CA: Human marginal zone B cells. Annu Rev Immunol 2009, 27:267-285.

45. Weller S, Braun MC, Tan BK, Rosenwald A, Cordier C, Conley ME, Plebani A, Kumararatne DS, Bonnet D, Tournilhac O, Tchernia G, Steiniger B, Staudt LM, Casanova JL, Reynaud CA, Weill JC: Human blood IgM "memory" B cells are circulating splenic marginal zone B cells harboring a prediversified immunoglobulin repertoire. Blood 2004, 104: 3647-3654.

46. Weller S, Mamani-Matsuda M, Picard C, Cordier C, Lecoeuche D, Gauthier F, Weill JC, Reynaud CA: Somatic diversification in the absence of antigendriven responses is the hallmark of the $\operatorname{lgM}+\lg D+C D 27+B$ cell repertoire in infants. J Exp Med 2008, 205:1331-1342

47. Bouaziz J-D, Le Buanec H, Saussine A, Bensussan A, Bagot M: IL-10 producing regulatory $B$ cell in mice and humans: State of the art. Curr Mol Med 2012, 12:519-527.

48. Vitale G, Mion F, Pucillo C: Regulatory B cells: Evidence, developmental origin and population diversity. Molecular Immunol 2010, 48:1-8.

49. Kardava L, Moir S, Wang W, Ho J, Buckner CM, Posada JG, O'Shea MA, Roby G, Chen J, Sohn HW, Chun TW, Pierce SK, Fauci AS: Attenuation of HIV-associated human B cell exhaustion by siRNA downregulation of inhibitory receptors. J Clin Invest 2011, 121:2614-2624.

50. Palmesino E, Moepps B, Gierschik P, Thelen M: Differences in CXCR4mediated signaling in B cells. Immunobiol 2006, 211:377-389.

51. Infantino S, Moepps B, Thelen M: Expression and regulation of the orphan receptor $\mathrm{RDC1}$ and its putative ligand in human dendritic and $\mathrm{B}$ cells. J Immunol 2006, 176:2197-2207.

52. Burns JM, Summers BC, Wang $Y$, Melikian A, Berahovich R, Miao Z, Penfold ME, Sunshine MJ, Littman DR, Kuo CJ, Wei K, McMaster BE, Wright K, Howard MC, Schall TJ: A novel chemokine receptor for SDF-1 and I-TAC involved in cell survival, cell adhesion, and tumor development. J Exp Med 2006, 203:2201-2212

53. Mariette X: B-Cell targeted therapies in Sjögren's syndrome. In Sjögren's syndrome diagnostic and Therapeutics Edited by: Ramos-Casals M, Stone S, Moutsoupoulos H, Springer 2012.

54. Mariette X, Quartuccio L, Seror R, Salvi S, Desmoulins F, Fabris M, Villeneuve S, Ravaud P, De Vita S: Results of the Beliss study, the first open phase 2 study of belimumab in primary Sjögren's syndrome. Arthritis Reum 2012, 64(Suppl):1079.

55. Flores-Borja F, Bosma A, Ng D, Reddy V, Ehrenstein M, Isenberg D, Mauri C: $\mathrm{CD} 19^{+} \mathrm{CD} 24^{\text {hi }} \mathrm{CD} 38^{\text {hi }} \mathrm{B}$ cells maintain regulatory $\mathrm{T}$ cells while limiting Th1 and Th17 differentiation. Sci Trans Med 2013, 5:173ra23.

doi:10.1186/ar4245

Cite this article as: Furuzawa-Carballeda et al:: Peripheral regulatory cells immunophenotyping in Primary Sjögren's Syndrome: a cross-sectional study. Arthritis Research \& Therapy 2013 15:R68.

\section{Submit your next manuscript to BioMed Central and take full advantage of:}

- Convenient online submission

- Thorough peer review

- No space constraints or color figure charges

- Immediate publication on acceptance

- Inclusion in PubMed, CAS, Scopus and Google Scholar

- Research which is freely available for redistribution

Submit your manuscript at www.biomedcentral.com/submit
Ciomed Central 